\title{
Soil Quality Indicators, Building Soil Organic Matter and Microbial Derived Inputs to Soil Organic Matter under Conservation Agriculture Ecosystem: A Review
}

\author{
N.C. Mahajan ${ }^{*}$, Kancheti Mrunalini' ${ }^{2}$, K.S. Krishna Prasad ${ }^{3}$, \\ R.K. Naresh $^{3}$ and Lingutla Sirisha ${ }^{4}$ \\ ${ }^{1}$ Institute of Agricultural Science, Department of Agronomy; Banaras Hindu University, \\ Varanasi, U. P., India \\ ${ }^{2}$ Department of Agronomy; Tamil Nadu Agricultural University, Coimbatore, \\ Tamil Nadu, India \\ ${ }^{3}$ Department of Agronomy; Sardar Vallabhbhai Patel University of Agriculture \& \\ Technology, Meerut, U.P., India \\ ${ }^{4}$ Department of Agronomy; Bihar Agricultural University, Sabour, Bihar., India \\ *Corresponding author
}

\section{Keywords \\ Conservation agriculture, Microbial biomass, Soil carbon, Soil quality indicators, Organic matter dynamics}

\section{Article Info}

Accepted: 15 January 2019 Available Online: 10 February 2019

\section{A B S T R A C T}

Agricultural intensification is placing tremendous pressure on the soil's capacity to maintain its functions leading to large-scale ecosystem degradation and loss of productivity in the long term. Therefore, there is an urgent need to find early indicators of soil health degradation in response to agricultural management. Our purpose was to review the literature in which a wide perspective of soil quality and the complex task of its assessment, considering the inherent and dynamic factors, are introduced. It focuses on the possibilities of applying and integrating the accumulated knowledge in agro-ecological land evaluation in order to predict soil quality. Landuse change, especially from conservation agriculture ecosystem (CA) to intensive agriculture, is negatively impacting soil quality and sustainability. Soil biological activities are sensitive indicators of such land-use impacts. Land use and management practices affect microbial properties in topsoil but have no effects in subsoil. Total organic $\mathrm{C}$ and $\mathrm{N}$ contents as well as microbial biomass were significantly higher in CA compared with conventional farming. The tillage treatments significantly influenced soil aggregate stability and OC distribution. Soil $\mathrm{OC}$ and $\mathrm{MBC}$ were at their highest levels for 1.0-2.0 mm aggregates, suggesting a higher biological activity at this aggregate size for the ecosystem. Compared with CT treatments, NT treatments increased MBC by $11.2 \%$, $11.5 \%$, and $20 \%$, and dissolved organic carbon (DOC) concentration by $15.5 \% 29.5 \%$, and $14.1 \%$ of bulk soil, $>0.25 \mathrm{~mm}$ aggregate, and $<0.25 \mathrm{~mm}$ aggregate in the $0-5 \mathrm{~cm}$ soil layer, respectively. Increased SOC stock in the surface $50 \mathrm{~kg} \mathrm{~m}^{-2}$ under ZT and PRB was compensated by greater SOC stocks in the $50-200$ and $200-400 \mathrm{~kg} \mathrm{~m}^{-2}$ interval under residue retained, but SOC stocks under CT were consistently lower in the surface $400 \mathrm{~kg} \mathrm{~m}^{-2}$.Soil organic carbon fractions (SOC), microbial biomasses and enzyme activities in the macro-aggregates are more sensitive to conservation tillage (CT) than in the micro-aggregates. Crop residues and rhizodeposits support higher microbial biomass, leading to enhanced enzyme activities in conservation agriculture ecosystem soil. Responses of macro-aggregates to straw return showed positively linear with increasing SOC concentration. Straw-C input rate and clay content significantly affected the response of SOC. Overall, straw return was an effective means to improve SOC accumulation, and soil quality. Straw return-induced improvement of soil nutrient availability may favour crop growth, which can in turn increase ecosystem C input. Tillage reduction and residue retention both increased the proportion of organic $\mathrm{C}$ and total $\mathrm{N}$ present in soil organic matter as microbial biomass. Microbial immobilization of available- $\mathrm{N}$ during the early phase of crops and its pulsed release later during the period of greater $\mathrm{N}$ demand of crops enhanced the degree of synchronization between crop demand and $\mathrm{N}$ supply. Overall, it indicates that land-use change significantly alters microbial properties in topsoil, with modest effects in subsoil. Microbial properties should be considered in environmental risk assessments as indicators of ecosystem disturbance caused by land-use and management practices. 


\section{Introduction}

Soil quality is one of the three components of environmental quality, besides water and air quality (Andrews et al., 2002). Water and air quality are defined mainly by their degree of pollution that impacts directly on human and animal consumption and health, or on natural ecosystems (Davidson, 2000). In contrast, soil quality is not limited to the degree of soil pollution, but is commonly defined much more broadly as "the capacity of a soil to function within ecosystem and land-use boundaries to sustain biological productivity, maintain environmental quality, and promote plant and animal health". This definition reflects the complexity and site-specificity of the belowground part of terrestrial ecosystems as well as the many linkages between soil functions and soil-based ecosystem services. Indeed, soil quality is more complex than the quality of air and water, not only because soil constitutes solid, liquid and gaseous phases, but also because soils can be used for a larger variety of purposes (Nortcliff, 2002). This multi-functionality of soils is also addressed when soil quality is defined from an environmental perspective as "the capacity of the soil to promote the growth of plants, protect watersheds by regulating the infiltration and partitioning of precipitation, and prevent water and air pollution by buffering potential pollutants such as agricultural chemicals, organic wastes, and industrial chemicals (Sims et al., 1997).

Soil is vital for the provision of soil-based ecosystem services that are essential for human wellbeing. These soil-based ecosystem services are the outcomes of the complex interplay of soil properties, environment, land use management and their interactions (Schulte et al., 2015; Ghaley et al., 2014) of which five key soil functions are identified; (a) primary productivity; (b) water regulation and purification; (c) carbon sequestration and regulation; (d) habitat for functional and intrinsic biodiversity; and (e) nutrient cycling and provision (Coyle et al., 2016). These five soil functions contribute to agricultural productivity, as well as the provision of other regulating and supporting ecosystem services. Soil management is a key driver that will determine whether soils are capable of supplying these multiple functions, which underscores the significance of soil custodianship (Lemanceau et al., 2016). As soils provide a suite of soil functions, optimization of one function can have tradeoffs with other soil functions. The objective of enhancing individual soil function viz. primary productivity function in the agriculture sector at the cost of other soil functions will depend on the local demands for the other soil function (Holland et al., 2004). Due to the competing demands for different soil functions, there is a need for an integrated, or holistic assessment, of the suite soil functions in order to mitigate trade-offs and to optimize supply which contrasts with efforts that focus only on individual soil functions. This study builds upon earlier reviews (Van den et al., 2010) and assesses the soil functions concurrently and the optimization of same, so that one soil function is not maximized at the cost of other soil functions.

Conventional farming (CONV) refers to mono-cropping, inversion tillage and residue removal, which is often, although not always, associated with contributing to adverse effects on soil functions. Conservation Agriculture (CA) practice constitutes no-till combined with residue retention and crop rotation (Hobbs et al., 2008) as an alternative to optimize the provision of soil functions. In a framework of soil custodianship, CA is practiced to optimize available resources whilst minimizing external inputs (Kertész and Madarász, 2014) and soil degradation (Fereres et al., 2014). Despite reported 
benefits, such as improved soil fertility, crop growth, better water infiltration, increased biological activity, decreased soil erosion and reduced labour, machinery use and fuel costs. Hence, there is a need to assess the effects of $\mathrm{CA}$ and CONV practices on soil functions in order to better understand their potentials to optimize soil functions and to provide evidence to support more sustainable outcomes.

In general, the total organic carbon (OC) is the amount of carbon in the soil related to living organisms or derived from them. Increasing the quantity of OC stored in soil may be one option for decreasing the atmospheric concentration of carbon dioxide $\left(\mathrm{CO}_{2}\right)$, a major greenhouse gas. Increasing the amount of OC stored in soil may also improve soil quality as OC contributes to many beneficial physical, chemical, and biological processes in the soil ecosystem (Fig. 1a). When OC in soil is below $1 \%$, soil health is low and yield potential may be constrained (Kay \& Angers, 1999).

The quantity of OC stored in soil is the difference between all OC inputs and losses from a soil. The main inputs of $\mathrm{OC}$ in irrigated farming systems are from crop residues, plant roots and animal manure. Inputs of plant material are generally higher when plant growth is denser.

Losses of OC from soil occur through decomposition by microorganisms, erosion of the surface soil, and withdrawal in plant and animal production. During decomposition, microorganisms convert about half of the OC to $\mathrm{CO}_{2}$. This process is continual, thus without a steady supply of OC, the quantity stored in the soil will decrease over time.

Losses by erosion may heavily impact the quantity of OC storage due to the heavy concentration of $\mathrm{OC}$ as small particles in the surface soil layer that are easily eroded Withdrawal of $\mathrm{OC}$ in plant and animal production is also an important loss of OC from soil. Harvested materials such as grain, hay, feed, and forage, all represent loss of OC for plant and animal production.

Ingram and Fernandes, (2001) reported that the management practices determine the actual storage of OC in soil by increasing inputs of organic matter via plant production and decreasing losses (Fig. 1b). Practices that can increase the amount of total OC stored in soil include:

Providing optimal nutrition, increasing water use efficiency, and decreasing disease. Maximising plant growth generally increases inputs of OC to soil in shoot material, roots and root exudates.

Maximising the period where plants are growing by shortening fallows, converting from cropping to pasture, or converting from annual to perennial pasture. Growing plants for longer periods each year generally increases inputs of OC to soil.

Reducing soil disturbance by retaining stubble, maintaining ground cover and reducing compaction by vehicles and stock. Improving soil structure can increase the amount of OC stored in soil by reducing losses of OC from soil by decomposition and erosion.

Oliveira et al., (2017) reported that the rate of soil $\mathrm{C}$ loss due to sugarcane straw harvest decreases from $0.19 \mathrm{Mg} \mathrm{ha}^{-1} \mathrm{yr}^{-1}$ (conventional cultivation) to $0.11 \mathrm{Mg} \mathrm{ha}^{-1}$ $\mathrm{yr}^{-1}$ when no-tillage is adopted (Fig. 2a). Thus, conservacionist management practices can also increase nutrient cycling, water storage, biological activity as well as the soil resistance to structural degradation (Franzluebbers, 2015; Stavi et al., 2016). 
Stavi et al., (2016) reported that crop residue harvest also makes the soil more susceptible to structural degradation, leading to compaction and consequently, resulting in lower infiltration and storage of water, and decreased plant root growth. Furthermore, crop residues act as physical/ mechanical barriers that help to protect the soil against raindrop impact, which reduces the risk of erosion. In addition, crop residue mulch acts as a temperature isolator, reducing the amplitude of soil temperature and water evaporation (Fig. 2b).

Mehra et al., (2018) revealed that soils have become one of the most endangered natural resources in the world. Each year,an estimated 25-40 billion tons of fertile soil are lost globally. Hence, improving soil health through sustainable land management should be a common goal for land managers, to protect, maintain and build their most vital resource - soils. Soils are the major reservoir of $\mathrm{C}$ in terrestrial ecosystems, and soil $\mathrm{C}$ plays a dynamic role in influencing the global $\mathrm{C}$ cycle and climate change (Fig. 3a) while regulating soil health and productivity (Singh et al., 2018). Soil contains $C$ in two forms: soil organic $\mathrm{C}$ (SOC) and soil inorganic $\mathrm{C}$ (SIC), with most soils having more SOC than SIC (Fig. 3a). Thus far, enormous scientific progress has been attained in understanding soil functional characteristics relating to SOC stocks and $\mathrm{C}$ dynamics in agroecosystems (Stockmann et al., 2013).

Thornton et al., (2014) revealed that a wellknown fact that intensive tillage, especially using mouldboard or disc ploughs that invert the profile, disturbs the soil's physical stability and may impact root growth and belowground $\mathrm{C}$ allocation. Now advanced tillage systems such as precision tillage and strategic tillage have to optimize edaphic conditions influence microbial and root activity, which depend on ecological niches
(Fig. 3b). For example, low-intensity tillage may create a favourable environment for root activity and belowground $\mathrm{C}$ allocation in some dryland cropping systems (e.g. canola vs wheat) with minimal or no negative impacts on soil structure (Sarker et al., 2017). Lal (2000) reported that crop yields decrease exponentially with increasing aridity as the shortage of available soil moisture can also influence the availability and transportation of soil nutrients to the plant. Under optimum moisture conditions, the increase of root zone temperature from $15-18^{\circ} \mathrm{C}$ to $25-29^{\circ} \mathrm{C}$ enhanced the nutrient uptake up to $100-$ $300 \%$, by increasing the root surface area and thus the rate of nutrient diffusion and water influx.

Soil biodiversity consists of soil microflora, soil microfauna and macrofauna. These soil organisms are the main drivers for $\mathrm{C}$ and nutrient cycling in pedosystems. Plant roots also play an important role because of their symbiotic relationships with soil rhizobia and mycorrhiza, and microbes in the rhizosphere, and these relationships can be impacted by climate change (McNear, 2013). Changes in the diversity and distribution of different biotic species in soil impact ongoing functional interactions among different soil organisms and plants, with impacts on plant nutrition and plant resistance to biotic and abiotic stresses. These biological interactions among different soil community members and plants act cross-functionally, which can be beneficial, minimizing adverse impacts to ecological functions and services from climatic abnormalities (Vandenkoornhuyse et al., 2015).

It is now understood that microbes play a key role in converting crop residues and other inputs in the soil ecosystem. Microbes can take carbon sources and convert them to various organic molecules such as proteins, lipids, and complex sugars. It is these that 
make up the bank of SOM, or soil humus, from which we derive agronomic benefit. Fertility plans should account for crop residue and nutrient removal to build soil health and fertility. By focusing on the health of the soil and the microbial communities in the soil, we are most likely to optimize soil organic matter formation, increase crop yields and improve plant health (Amaranthus and Allyn, 2013) (Fig. 4a).

Many actions can be taken to preserve and rebuild soils to maximize the retention and recycling of organic matter and nutrients (Bot and Benites, 2005). This can be accomplished by minimizing losses to leaching, runoff and erosion through reduced tillage, diverse crop rotations and fertilizer selection (Cookson et al., 2008) (Fig. 4a). Soil type, climate and management influence organic matter inputs to soil and its turnover or decomposition. The different fractions of SOM turn over at vastly different rates (Fig. 4b).

Soil biota is considered an important and labile fraction of soil organic matter involved in energy and nutrient cycling. It has been well established that the more dynamic characteristics such as microbial biomass, soil enzyme activity and soil respiration respond more quickly to changes in crop management practices or environmental conditions than do characteristics such as total soil organic matter (Doran et al., 1996) (Fig. 5a). Microbial biomass carbon is a relatively small (approximately 1-4\% of total soil organic carbon), labile fraction that quickly responds to $\mathrm{C}$ availability and also strongly infl uenced by management practices and system perturbations (Smith and Paul 1990 ).

Estimates of yearly greenhouse gas reductions for organic agriculture and soil sequestration range from $12 \%$ to $100 \%$. But at least $17 \%$ of each year's GHG production can be trapped in the soil by organic methods. Smith et al.,
(2008) estimated that organic agriculture methods could offset 5.5 to $6.0 \mathrm{Gt} \mathrm{CO}_{2} \mathrm{e} / \mathrm{yr}$, about $12 \%$ of total GHG emissions in 2012 . Calculations included both croplands and grasslands, and included non- $\mathrm{CO}_{2}$ gases.

Scialabba and Muller-Lindenlauf (2010) calculated that eliminating synthetic fertilizers would reduce $\mathrm{GHG}$ emissions by $1.26 \mathrm{Gt}$ $\mathrm{CO}_{2} \mathrm{e} / \mathrm{yr}, 2.5 \%$ of total 2012 GHG. They estimated carbon sequestration could reduce total yearly GHG by $13-24 \%$. Estimates for carbon sequestration in organic crops range from $5-24 \%$ of each year's GHG emissions. Lal 2004a estimated that maximum sequestration rate for croplands was $1000 \mathrm{~kg}$ $\mathrm{C} / \mathrm{ha} / \mathrm{yr}$ (890 lb/acre/yr), giving $1.2 \mathrm{Gt} \mathrm{C/year}$ (4.4 Gt $\mathrm{CO}_{2} / \mathrm{yr}$ ). This number is about $8.8 \%$ of total $2012 \mathrm{GHG}\left(50 \mathrm{Gt} \mathrm{CO}_{2} \mathrm{e}\right)$. Lal 2004b estimated $0.9 \mathrm{Gt} \mathrm{C} /$ year $\left(3.3 \mathrm{Gt} \mathrm{CO}_{2} / \mathrm{yr}\right.$ ) over a 50 year period. That is about $6.6 \%$ of total GHG levels in 2012. Gattinger found cropland on organic farms sequestered $450 \mathrm{~kg}$ C/ha/yr (400lb/acre/yr) more than conventional farms. Extrapolation to all arable land (1369 million ha) gives $0.616 \mathrm{Gt}$ $\mathrm{C} / \mathrm{ha} / \mathrm{yr}$ (2.26 Gt $\mathrm{CO}_{2} / \mathrm{yr}$ ). This number is equal to $4.5 \%$ of $2012 \mathrm{GHG}$ emissions. Very conservatively, about $17 \%$ of the world's total greenhouse emissions could be trapped in the soil each year by organic methods. This number combines Gattinger's estimate for crops $(4.5 \%)$ with an average estimate $(13 \%)$ for pastures. Reductions are based on 2012 emission rates $\left(50 \mathrm{Gt} \mathrm{CO}_{2} \mathrm{e}\right)$. Paustian et al., (2016) found a similar number, $8 \mathrm{Gt} \mathrm{CO}_{2} \mathrm{e}$, or $16 \%$ of 2012 global emissions.

Organic livestock management Rodale Institute (2014), using the maximum figure of $3040 \mathrm{~kg} \mathrm{C} / \mathrm{ha} / \mathrm{yr}$ (2705 lb/acre/yr), calculated that potential GHG reduction due to improved pasture management could be a maximum 37 Gt $\mathrm{CO}_{2} \mathrm{e} / \mathrm{yr}$, about $74 \%$ of total GHG in 2012. An average increase $(540 \mathrm{~kg} \mathrm{C} / \mathrm{ha} / \mathrm{yr})$ in sequestered carbon could remove about $6.6 \mathrm{Gt}$ 
$\mathrm{CO}_{2} \mathrm{e} / \mathrm{yr}$, about $13 \%$ of total GHG in 2012

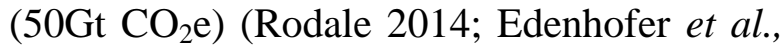
2014).

Naresh et al., (2018) also found that the highest SOC stock of $72.2 \mathrm{Mg} \mathrm{C}$ ha $^{-1}$ was observed in $\mathrm{F}_{6}$ with $\mathrm{T} 6$ followed by that of $64 \mathrm{Mg} \mathrm{C}$ ha ${ }^{-1}$ in $\mathrm{F}_{4}$ with $\mathrm{T}_{2}>$ that in $\mathrm{F}_{3}$ with $\mathrm{T}_{4}$ $\left(57.9 \mathrm{Mg} \mathrm{C} \mathrm{ha}^{-1}\right)>\mathrm{F}_{5}$ with $\mathrm{T}_{1}\left(38.4 \mathrm{Mg} \mathrm{C} \mathrm{ha}^{-1}\right)$ $=\mathrm{F}_{7}$ with $\mathrm{T}_{5}\left(35.8 \mathrm{Mg} \mathrm{C}^{-1}\right)$, and the lowest $\left(19.9 \mathrm{Mg} \mathrm{C} \mathrm{ha}{ }^{-1}\right)$ in $\mathrm{F}_{1}$ with $\mathrm{T}_{7}$. Relatively higher percentage increase of SOC stock was observed in $\mathrm{F}_{6}$ with $\mathrm{T}_{6}$ treatment $(56.3 \mathrm{Mg} \mathrm{C}$ $\mathrm{ha}^{-1}$ ) followed by $\mathrm{F}_{4}$ with $\mathrm{T}_{2}\left(51.4 \mathrm{Mg} \mathrm{C} \mathrm{ha}^{-1}\right)$ and $\mathrm{F}_{3}$ with $\mathrm{T}_{1}\left(48.4 \mathrm{Mg} \mathrm{C}^{-1}\right.$ ). Majumder et al., (2008) reported $67.9 \%$ of C stabilization from FYM applied in a rice-wheat system in the lower Indo-Gangetic plains. Naresh et al., (2015) reported that average SOC concentration of the control treatment was $0.54 \%$, which increased to $0.65 \%$ in the RDF treatment and $0.82 \%$ in the RDF+ FYM treatment. Compared to $F_{1}$ control treatment the $\mathrm{RDF}+\mathrm{FYM}$ treatment sequestered 0.33 $\mathrm{Mg} \mathrm{C} \mathrm{ha}{ }^{-1} \mathrm{yr}^{-1}$ whereas the NPK treatment sequestered $0.16 \mathrm{Mg} \mathrm{C}^{-1} \mathrm{yr}^{-1}$.

Zibilsk et al., (2002) reported that the No-till resulted in significantly greater soil organic $\mathrm{C}$ in the top $4 \mathrm{~cm}$ of soil, where the organic $\mathrm{C}$ concentration was $58 \%$ greater than in the top $4 \mathrm{~cm}$ of the plow-till treatment. In the $4-8 \mathrm{~cm}$ depth, organic $\mathrm{C}$ was $15 \%$ greater than the plow-till control (Fig. 6a). The differences were relatively modest, but consistent with organic C gains observed in hot climates where conservation tillage has been adopted. Higher concentrations of total soil $\mathrm{N}$ occurred in the same treatments; however a significant reduction in $\mathrm{N}$ was detected below $12 \mathrm{~cm}$ in the ridge-till treatment (Fig. 6c). The relatively low amount of readily oxidizable $\mathrm{C}$ (ROC) in all tillage treatments suggests that much of the soil organic $\mathrm{C}$ gained is humic in nature which would be expected to improve $\mathrm{C}$ sequestration in this soil (Fig. 6b).
Naresh et al., (2018) revealed that the quantities of SOC at the $0-400 \mathrm{~kg}$ of soil $\mathrm{m}^{-2}$ interval decreased under $\mathrm{T}_{1}, \mathrm{~T} 4$ and $\mathrm{T}_{7}$ treatments evaluated. Stocks of SOC in the top $400 \mathrm{~kg}$ of soil m $\mathrm{m}^{-2}$ decreased from 7.46 to $7.15 \mathrm{~kg}$ of $\mathrm{C} \mathrm{m}^{-2}$ represented a change of $0.31 \pm 0.03 \mathrm{~kg}$ of $\mathrm{C} \mathrm{m}^{-2}$ in $\mathrm{T}_{1}, 8.81$ to $8.75 \mathrm{~kg}$ of $\mathrm{Cm}^{-2}$ represented a change of $-0.06 \pm 0.05$ $\mathrm{kg}$ of $\mathrm{C} \mathrm{m}^{-2}$ in $\mathrm{T}_{4}$, and 5.92 to 5.22 of $\mathrm{C} \mathrm{m}^{-2}$ represented a change of $-0.70 \pm 0.09 \mathrm{~kg}$ of $\mathrm{C}$ $\mathrm{m}^{-2}$ in $\mathrm{T}_{7}$ between 2000 and 2018 [Table 3]. Our results clearly show that for the given conditions of this study (climatic conditions, soil type, tillage system and nutrient) zero tillage and permanent raised with 4 and 6 tha $^{-1}$ of the residue retention evaluated treatments were able to sequester atmospheric $\mathrm{C}$ or even achieve a balance between inputs and outputs. Levels of SOC were clearly lower after 18 years of cultivation under without residue retention zero tillage, permanent raised beds and conventional tillage practices. Soil $\mathrm{C}$ content in the $400-800$ and $800-1200 \mathrm{~kg}$ of soil $\mathrm{m}^{-2}$ intervals performed similar change after 18 years. Changes over the length of the study averaged over tillage crop residue practices were $-0.07 \pm 0.09$ and $-0.05 \pm 0.02 \mathrm{~kg}$ $\mathrm{C} \mathrm{m}^{-2}$ in the $400-800$ and $800-1200 \mathrm{~kg}$ of soil $\mathrm{m}^{-2}$ intervals. This is equivalent to an average yearly change rate of -5.5 and $-3.9 \mathrm{~g} \mathrm{C} \mathrm{m}^{-2}$ $\mathrm{yr}^{-1}$ for each mentioned soil mass interval (Table 3).

Maharjan et al., (2017) observed that the total soil organic $\mathrm{C}$ was highest in organic farming (24 mg C g ${ }^{-1}$ soil) followed by conventional farming (15 $\mathrm{mg} \mathrm{C} \mathrm{g}^{-1}$ soil) and forest $(9 \mathrm{mg} \mathrm{C}$ $\mathrm{g}^{-1}$ soil) in the topsoil layer $(0-10 \mathrm{~cm}$ depth). Total C content declined with increasing soil depth, remaining highest in the organic farming soil al all depths tested. A similar trend was found for total $\mathrm{N}$ content in all three land uses (Fig. 8a), with organic farming soil possessing the highest total $\mathrm{N}$ content in both top and subsoil. 
Similarly, microbial $\mathrm{C}$ and $\mathrm{N}$ were also highest under organic farming, especially in the topsoil layer (350 and $46 \mathrm{mg} \mathrm{g}^{-1}$ soil, respectively), (Fig. 8a). However, conventional farming and forest soils had similar microbial biomass content. In subsoil, there were no significant effects of land-use changes on microbial biomass $\mathrm{C}$ and $\mathrm{N}$. Positive correlations were found for total soil $\mathrm{C}$ and $\mathrm{N}$ with microbial biomass $\mathrm{C}$ and $\mathrm{N}$.

Moreover, farmyard manure supplies readily available $\mathrm{N}$, resulting higher plant biomass. As a result, more crop residues are incorporated through tillage, which maintains higher OM ( $\mathrm{C}$ and $\mathrm{N}$ ) levels in surface layer (Fig. 8b). This also provides a favorable environment for microorganisms, contributing to a highly diverse and stable microbial community structure in conservation farming systems. In conventional farming, fallow periods in the crop rotation interrupt the continuous incorporation of crop residues, resulting in lower OM than for conservation farming. In addition, toxic effects of pesticides may reduce the microbial biomass in conventional farming. The activity of $\square$ glucosidase was higher in organic farming (199 nmol $\mathrm{g}^{-1}$ soil $\mathrm{h}^{-1}$ ) followed by conventional farming $\left(130 \mathrm{nmol} \mathrm{g}^{-1}\right.$ soil h$\left.^{-1}\right)$ and forest soil $\left(19 \mathrm{nmol} \mathrm{g}{ }^{-1}\right.$ soil $\left.\mathrm{h}^{-1}\right)$ in the topsoil layer. The activity of cellobiohydrolase was higher in organic farming compared to forest soil, but was similar in organic and conventional farming soil. In contrast, xylanase activity was higher under conventional farming $\left(27 \mathrm{nmol} \mathrm{g}^{-1}\right.$ soil $\left.\mathrm{h}^{-1}\right)$ followed by organic farming $\left(17 \mathrm{nmol} \mathrm{g}^{-1}\right.$ soil $\left.\mathrm{h}^{-1}\right)$ and forest soil $\left(12 \mathrm{nmol} \mathrm{g}{ }^{-1}\right.$ soil $\left.^{-1}\right)$, (Fig. 8c).

Li et al., (2018) reported that higher MBC and MBN were found in Calcaric Cambisol and Luvic Phaeozem than that in Ferralic Cambisol regardless of organic material type (Fig. 9a). When compared with the control, all organic material treatments significantly increased the MBC while only the $\mathrm{CM}$ and PM treatments significantly increased the MBN in the three soils. At the end of the $12^{\text {th }}$ month, the variance in $\mathrm{MBC}$ and $\mathrm{MBN}$ was primarily explained by the organic material type, and the contribution of the organic material type was significat and explained $45.3 \%$ of the variance in MBC and $29.5 \%$ of the variance in MBN. The WS, CS, WR and $\mathrm{CR}$ treatments significantly increased the MBC while only the WS and CS treatments significantly increased the MBN when compared with the control in the three soils (Fig. 9a). When compared with the end of the $1^{\text {st }}$ month, the MBC at the end of the $12^{\text {th }}$ month decreased by $21.5 \pm 28.7 \%$, and the MBN at the end of the $12^{\text {th }}$ month increased by $62.9 \pm 143.7 \%$ in the three soils (Fig. 9a).

Kantola et al., (2017) observed that the POM$\mathrm{C}$ in surface soil $(0-10 \mathrm{~cm})$ increased for all crops from 1.59 to $1.79 \mathrm{~g} \mathrm{C} \mathrm{kg}^{-1}$ soil at the beginning of the experiment to 2.54-3.01 $\mathrm{g} \mathrm{C}$ $\mathrm{kg}^{-1}$ soil after six years. This indicates new organic inputs are not priming the system for a major loss of POM with the establishment of $\mathrm{C}_{4}$ bioenergy crops, instead POM-C accumulated between 2008 and 2014 supplemented existing POM, resulting in an overall POM increase (Fig. 9b). However, changes in SOC in surface soil $(0 \mathrm{e} 10 \mathrm{~cm})$ over time, while not statistically significant annually within a crop type, contributed to differences among crops after six years. In the surface soil $(0-10 \mathrm{~cm})$, soil $\mathrm{C}$ under maize/soybean showed an initial positive trend between 2008 and 2010, followed by a decline between 2010 and 2014, resulting in the lowest concentration of SOC of all treatments (Fig. 9c).

Murugan et al., (2013) revealed that the GRT and NT treatments increased the stocks of SOC $(+7 \%)$ and microbial biomass $\mathrm{C}(+20$ $\%)$ in comparison with the MBT treatment. 
The differences between the GRT and NT were small, but there were more positive effects for the GRT treatment in most cases (Fig. 10a). Geraei et al., (2016) reported that the $\mathrm{P}$ soils showed a better and different quality of organic $\mathrm{C}$ than other land use systems, which was indicated by the highest proportion of microbial biomass $\mathrm{C}(3.3 \%)$, permanganate oxidizable $\mathrm{C}(4.8 \%)$, and cold$(0.55 \%)$ and hot-water extractable organic $\mathrm{C}$ (3.7\%), but the lowest proportion of nonlabile C (95.2\%) to the TOC contents of the soils (Fig. 10b). In contrast, the agricultural land use systems with conventional tillage practices showed the minimum contents of microbial biomass $C$ (Fig. 10b), and microbial quotient. The conventional tillage practices have been shown to enhance soil aeration. The oxidation of organic $\mathrm{C}$ is accelerated through exposure of the organic matter to microbial attack, (Sharma et al., 2014). Cardinael et al., (2018) also found that the reduction in crop OC inputs was offset by OC inputs from the tree roots and tree litter-fall. Total root OC inputs in the alleys (crop + tree roots) and in the control plot (crop roots) were very similar, respectively 2.43 and $2.29 \mathrm{tCha}^{-1}$ $\mathrm{yr}^{-1}$. Alleys received $0.60 \mathrm{tCha}^{-1} \mathrm{yr}^{-1}$ more total aboveground biomass (crop residues + tree litter-fall) than the control, which was added to the plough layer.

Aulakh et al., (2013) showed that PMN content after 2 years of the experiment in 0-5 $\mathrm{cm}$ soil layer of $\mathrm{CT}$ system, $\mathrm{T}_{2}, \mathrm{~T}_{3}$ and $\mathrm{T}_{4}$ treatments increased PMN content from 2.7 $\mathrm{mgkg}^{-1} 7 \mathrm{~d}^{-1}$ in control $\left(\mathrm{T}_{1}\right)$ to $2.9,3.9$ and 5.1 $\mathrm{mgkg}^{-1} 7 \mathrm{~d}^{-1}$ without $\mathrm{CR}$, and to $6.9,8.4$ and $9.7 \mathrm{mg} \mathrm{kg}^{-1} 7 \mathrm{~d}^{-1}$ with $\mathrm{CR}\left(\mathrm{T}_{6}, \mathrm{~T}_{7}\right.$ and $\left.\mathrm{T} 8\right)$, respectively. The corresponding increase of PMN content under CA system was from 3.6 $\mathrm{mgkg}^{-1} 7 \mathrm{~d}^{-1}$ in control to $3.9,5.1$ and 6.5 $\mathrm{mgkg}^{-1} 7 \mathrm{~d}^{-1}$ without CR and to 8.9, 10.3 and $12.1 \mathrm{mgkg}^{-1} 7 \mathrm{~d}^{-1}$ with CR. PMN, a measure of the soil capacity to supply mineral $\mathrm{N}$, constitutes an important measure of the soil health due to its strong relationship with the capability of soil to supply $\mathrm{N}$ for crop growth.

Xiao et al., (2016) showed that the MBC in aggregates and bulk soil in other land uses decreased compared with that in enclosure land (Fig. 10c). Further, the maize field had the lowest MBC. Moreover, the MBC in small micro-aggregates of prescribed-burning land (1850.62 mg kg-1) was significantly higher than that of enclosure land (1219.90 $\left.\mathrm{mg} \mathrm{kg}^{-1}\right)$. The pasture and maize fields had much lower $\mathrm{MBC}$ in micro-aggregates (623.36 $\mathrm{mgkg}^{-1}$ and $514.30 \mathrm{mgkg}^{-1}$, respectively). However, the $\mathrm{MBC}$ in large macro-aggregates did not differ significantly among all land uses. In the three aggregates, MBC was the highest in small macroaggregates, followed by large macroaggregates and micro-aggregates (Fig. 10c). The $\mathrm{C}_{\text {mic }}$ : $\mathrm{C}_{\text {org }}$ ratios ranged between $1.71 \%$ and $3.44 \%$ (Fig. 10c). Compared to enclosure land, the ratios in other land uses increased in aggregates and bulk soil. The highest $\mathrm{C}_{\text {mic }}$ : $\mathrm{C}_{\text {org }}$ ratio (3.44\%) was observed in small macro-aggregates. This is mainly because the large radius of large aggregates could limit the $\mathrm{O}_{2}$ concentration and gas diffusion required by microbes (Gupta and Germida, 2015; Jiang et al., 2011). Thus, large macroaggregates might diminish the impacts of land uses and facilitate the maintenance of a stable microbial biomass.

Zheng et al., (2018) revealed that the SOC storage in macro-aggregates under different treatments significantly decreased with soil depth (Table 5). However, no significant variation was observed in the microaggregate associated C storage with depth. SOC storage increased with aggregate size from $1 \pm 2$ to $>$ $2 \mathrm{~mm}$ and decreased with a decrease in aggregate size. The SOC storage in macroaggregates of all sizes from $0-30 \mathrm{~cm}$ depth was higher in the ST treatment than in other treatments. From $30-60 \mathrm{~cm}$, trends were less 
clear. SOC storage in micro-aggregates showed the opposite trend, with significantly higher levels in the CT treatment from 0 $30 \mathrm{~cm}$, and no significant differences between treatments below this depth.

Crop residues provide a source of organic matter, so when returned to soil the residues increase the storage of organic $\mathrm{C}$ and $\mathrm{N}$ in soil, whereas their removal results in a substantial loss of organic $\mathrm{C}$ and $\mathrm{N}$ from the soil system (Malhi and Lemke 2007). Therefore, one would expect a dramatic increase in organic $\mathrm{C}$ in soil from a combination of $\mathrm{ZT}$, straw retention and proper/ balanced fertilization (Malhi et al., 2011b). Naresh et al., (2016) also found significantly higher POC content was probably also due to higher biomass $\mathrm{C}$. Results on PON content after 3-year showed that in $0-5 \mathrm{~cm}$ soil layer of CT system, $\mathrm{T}_{1}$, and $\mathrm{T}_{5}$ treatments increased $\mathrm{PON}$ content from $35.8 \mathrm{mgkg}^{-1}$ in $\mathrm{CT}\left(\mathrm{T}_{9}\right)$ to 47.3 and 67.7 $\mathrm{mg} \cdot \mathrm{kg}^{-1}$ without $\mathrm{CR}$, and to $78.3,92.4$ and $103.8 \mathrm{mgkg}^{-1}$ with CR @ 2, 4and 6 tha $^{-1}$, respectively.

Table.1 Profile soil organic carbon (SOC) as affected by $18 \mathrm{yr}$ of tillage crop residue practices and nutrient management practices [Source: Naresh et al., 2018]

\begin{tabular}{|c|c|c|c|c|c|c|c|c|c|}
\hline \multirow{4}{*}{$\begin{array}{l}\text { Tillage crop } \\
\text { residue } \\
\text { practices }\end{array}$} & \multirow{4}{*}{$\begin{array}{l}\text { Initial } \\
\text { SOC stock }\end{array}$} & \multicolumn{8}{|c|}{2018} \\
\hline & & \multicolumn{8}{|c|}{$\mathrm{MgCha}$} \\
\hline & & \multicolumn{8}{|c|}{ Fertilization } \\
\hline & & $\mathrm{F}_{1}^{* *}$ & $F_{2}$ & $F_{3}$ & $F_{4}$ & $\mathrm{~F}_{5}$ & $\mathrm{~F}_{6}$ & $\mathrm{~F}_{7}$ & Mean \\
\hline $\mathrm{T}_{1}$ & $20.9 \pm 1.6$ & $19.2 \pm 1.3^{\mathrm{D} \dagger}$ & $26.9 \pm 1.6^{\mathrm{D}}$ & $54.1 \pm 1.7^{\mathrm{D}}$ & $63.3+2.8^{C}$ & $36.9 \pm 1.5^{\mathrm{C}}$ & $70.5 \pm 3.7^{D}$ & $35.1 \pm 1.7^{\mathrm{D}}$ & $43.7 \pm 2.0^{\mathrm{D}}$ \\
\hline $\mathrm{T}_{2}$ & & $23.0 \pm 1.7^{\mathrm{B}}$ & $33.5+2.5^{\mathrm{D}}$ & $65.8 \pm 2.0^{B}$ & $70.9+3.7^{\mathrm{A}}$ & $44.9 \pm 1.9^{B}$ & $81.6 \pm 4.2^{B}$ & $39.8 \pm 1.3^{\mathrm{D}}$ & $51.4 \pm 2.5^{\mathrm{B}}$ \\
\hline $\mathrm{T}_{3}$ & & $16.7 \pm 1.3^{D}$ & $23.4 \pm 1.9^{\mathrm{B}}$ & $52.0 \pm 1.6^{\mathrm{D}}$ & $58.6 \pm 1.6^{\mathrm{D}}$ & $33.2 \pm 1.5^{\mathrm{C}}$ & $63.5 \pm 3.3^{E}$ & $31.3 \pm 0.1^{\mathrm{B}}$ & $39.9 \pm 1.6^{\mathrm{D}}$ \\
\hline$T_{4}$ & & $20.5 \pm 1.5^{\mathrm{C}}$ & $30.7 \pm 2.4^{B}$ & $62.6 \pm 1.9^{\mathrm{C}}$ & $69.4+3.3^{B}$ & $39.7 \pm 1.3^{B}$ & $79.1 \pm 4.1^{\mathrm{C}}$ & $36.7 \pm 1.5^{\mathrm{C}}$ & $48.4 \pm 2.3^{\mathrm{C}}$ \\
\hline$T_{5}$ & & $18.0 \pm 1.3^{D}$ & $25.5 \pm 2.1^{\mathrm{A}}$ & $53.4 \pm 1.7^{\mathrm{D}}$ & $61.3 \pm 2.1^{A}$ & $34.4 \pm 1.3^{D}$ & $67.0 \pm 1.4^{B}$ & $32.1 \pm 0.1^{\mathrm{B}}$ & $41.7 \pm 1.4^{\mathrm{D}}$ \\
\hline $\mathrm{T}_{6}$ & & $26.5 \pm 1.9^{A}$ & $42.5 \pm 3.1^{A}$ & $68.5 \pm 2.1^{A}$ & $73.0+3.6^{A}$ & $49.7 \pm 1.8^{C}$ & $85.7 \pm 4.5^{\mathrm{A}}$ & $48.2 \pm 2.1^{A}$ & $56.3 \pm 2.7^{A}$ \\
\hline $\mathrm{T}_{7}$ & & $15.8 \pm 1.2^{\mathrm{E}}$ & $19.3 \pm 1.8^{\mathrm{C}}$ & $49.0 \pm 1.5^{\mathrm{E}}$ & $51.7+2.5^{\mathrm{D}}$ & $29.8 \pm 1.2^{\mathrm{E}}$ & $58.0 \pm 1.3^{\mathrm{C}}$ & $27.4 \pm 1.7^{\mathrm{D}}$ & $28.7 \pm 1.6^{E}$ \\
\hline Mean & & $19.9 \pm 1.5^{\mathrm{D}}$ & $28.8 \pm 2.2^{\mathrm{B}}$ & $57.9 \pm 1.8^{\mathrm{D}}$ & $64.0 \pm 2.8^{C}$ & $38.4 \pm 1.5^{\mathrm{C}}$ & $72.2 \pm 3.2^{\mathrm{C}}$ & $35.8 \pm 1.2^{\mathrm{D}}$ & - \\
\hline
\end{tabular}

Table.2 Groups of soil organisms as indicators: relation to soil functions and processes involved

\begin{tabular}{|c|c|c|c|}
\hline Soil organism & Soil functions & Processes involved & Reference \\
\hline \multicolumn{4}{|l|}{ Macroorganisms (fauna) } \\
\hline Earthworms (macrofauna) & $\begin{array}{l}\text { Soil structure formation, Water, pollutant and } \\
\text { nutrient cycling }\end{array}$ & $\begin{array}{l}\text { Soil aggregation, porosity, } \\
\text { decomposition, humification, organic matter } \\
\text { distribution }\end{array}$ & $\begin{array}{l}\text { (Blouin et al., 2013; Lavelle et } \\
\text { al., 2006) }\end{array}$ \\
\hline Nematodes (microfauna) & $\begin{array}{l}\text { Nutrient cycling, decomposition, population } \\
\text { regulation, biodiversity and habitat }\end{array}$ & $\begin{array}{l}\text { Grazing on microorganisms, control of pests } \\
\text { and diseases }\end{array}$ & $\begin{array}{l}\text { (Mulder et al.,2005; Neher, } \\
\text { 2001;Schloter et al., 2003) }\end{array}$ \\
\hline Protists (micro-/mesofauna) & Nutrient cycling, population regulation & Grazing on microorganisms & $\begin{array}{l}\text { (Foissner, 1999; Riches et al., } \\
\text { 2013) }\end{array}$ \\
\hline Collembola (mesofauna) & $\begin{array}{l}\text { Decomposition, water and nutrient cycling, } \\
\text { degradation of pollutants }\end{array}$ & Fragmentation of residues, biopores & \multirow{4}{*}{$\begin{array}{l}\text { (Brussaard et al.,2004; Cardoso } \\
\text { et al.,2013; Pulleman et } \\
\text { al.,2012; Ruf et al., 2003) }\end{array}$} \\
\hline Enchytraeids (mesofauna) & Decomposition, soil structure formation & $\begin{array}{l}\text { Soil aggregation, porosity, decomposition, } \\
\text { humification, organic matter distribution }\end{array}$ & \\
\hline Mites (mesofauna) & Population regulation & Fragmentation of residues, biopores & \\
\hline Macroarthropods (macrofauna) & Nutrient cycling, soil structure formation & $\begin{array}{l}\text { Stimulation of microbial activity, biopores, } \\
\text { plant pests }\end{array}$ & \\
\hline \multicolumn{4}{|l|}{ Microorganisms (microbes) } \\
\hline Bacteria & Nutrient cycling, plant health promotion & $\begin{array}{l}\text { Symbiotic association, decomposition, } \\
\text { mineralization and transformation of organic } \\
\text { material }\end{array}$ & $\begin{array}{l}\text { (Brussaard, 2012; Brussaard et } \\
\text { al., 2004; Lehman et al., 2015; }\end{array}$ \\
\hline Fungi & $\begin{array}{l}\text { Nutrient cycling, soil structure formation, } \\
\text { carbon sequestration, plant health promotion }\end{array}$ & $\begin{array}{l}\text { Symbiotic association, decomposition and } \\
\text { transformation of recalcitrant material. }\end{array}$ & $\begin{array}{l}\text { Pulleman et al., 2012; Schloter } \\
\text { et al., 2003) }\end{array}$ \\
\hline
\end{tabular}


Table.3 Soil organic carbon (SOC) stocks and annual rate of change in multiple soil mass intervals in 2000 and in 2018 at Meerut, U.P. [Source: Naresh et al., 2018]

\begin{tabular}{|c|c|c|c|c|c|c|c|c|c|c|c|c|}
\hline \multirow{4}{*}{$\begin{array}{l}\text { Tillage } \\
\text { crop } \\
\text { residue } \\
\text { practices }\end{array}$} & \multicolumn{12}{|c|}{ Soil Organic Carbon ( \pm Standard error) } \\
\hline & \multicolumn{3}{|c|}{$\begin{array}{l}0-400 \mathrm{~kg} \text { of soil } \mathrm{m}^{-2} \\
\text { (approx. } 0-30 \mathrm{~cm} \text { ) }\end{array}$} & \multirow{2}{*}{$\begin{array}{l}\text { Annual } \\
\text { SOC } \\
\text { change } \\
\text { rate g of } \\
\mathrm{Cm}^{-2} \mathrm{yr}^{-}\end{array}$} & \multicolumn{3}{|c|}{$\begin{array}{l}400-800 \mathrm{~kg} \text { of soil m} \mathrm{m}^{-2} \\
\text { (approx. } 30-60 \mathrm{~cm} \text { ) }\end{array}$} & \multirow{2}{*}{\begin{tabular}{l} 
Annual \\
\multicolumn{1}{c}{ SOC } \\
change \\
rate $\mathrm{g}$ of \\
$\mathrm{Cm}^{-2} \mathrm{yr}^{-}$
\end{tabular}} & \multicolumn{3}{|c|}{$\begin{array}{l}800-1200 \mathrm{~kg} \text { of soil m-2 (approx. } \\
60-90 \mathrm{~cm})\end{array}$} & \multirow{2}{*}{$\begin{array}{l}\text { Annual } \\
\text { SOC } \\
\text { change } \\
\text { rate g of } \\
\mathrm{Cm}_{1}^{-2} \mathrm{yr}^{-}\end{array}$} \\
\hline & 2000 & 2018 & Difference & & 2000 & 2018 & Difference & & 2000 & 2018 & Difference & \\
\hline & \multicolumn{11}{|c|}{ 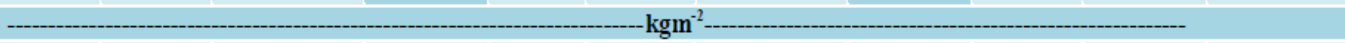 } & \\
\hline $\mathrm{T}_{1}$ & 7.46 & $7.15^{*}$ & $-0.31 \pm 0.03$ & -28.2 & 5.39 & 5.65 & $-0.26 \pm 0.09$ & -6.9 & 3.14 & 3.12 & $-0.02 \pm 0.01$ & -1.8 \\
\hline $\mathbf{T}_{2}$ & $8.98 *$ & 9.77 & $0.79 \pm 0.2$ & 66.2 & 7.03 & 7.11 & $0.08 \pm 0.2$ & 1.5 & 3.72 & 3.81 & $0.09 \pm 0.11$ & 8.1 \\
\hline $\mathrm{T}_{3}$ & $9.18^{*}$ & 9.87 & $-0.69 \pm 0.2$ & 57.4 & 7.62 & 7.64 & $0.02 \pm 0.2$ & 7.0 & 5.04 & 5.08 & $0.04 \pm 0.01$ & 1.7 \\
\hline$T_{4}$ & 8.81 & 8.75 & $-0.06 \pm 0.05$ & -25.7 & 5.82 & $5.31^{*}$ & $-0.51 \pm 0.2$ & -4.5 & 2.93 & 2.67 & $-0.26 \pm 0.02$ & -4.7 \\
\hline $\mathrm{T}_{5}$ & 8.12 & $9.11^{*}$ & $0.99 \pm 0.2$ & 82.1 & 5.47 & 5.57 & $0.10 \pm 0.09$ & 8.8 & 3.38 & 3.47 & $0.01 \pm 0.11$ & 5.4 \\
\hline $\mathrm{T}_{6}$ & 9.15 & 9.29 & $0.14 \pm 0.9$ & 19.6 & 5.72 & 5.88 & $0.16 \pm 0.09$ & 7.3 & 4.57 & 4.58 & $0.01 \pm 0.01$ & 0.6 \\
\hline $\mathrm{T}_{7}$ & 5.92 & 5.22 & $-0.70 \pm 0.09$ & -13.4 & 4.05 & 3.98 & $-0.07 \pm 0.09$ & -5.5 & 2.42 & 2.37 & $-0.05 \pm 0.02$ & -3.9 \\
\hline
\end{tabular}

*Significant difference between years at $\alpha=0.05$

Table.4 Strategies of soil health management as per NRCS-USDA (2016)

\begin{tabular}{|c|c|c|}
\hline Strategy & What does it do? & How does it help? \\
\hline $\begin{array}{l}\text { Conservation Crop Rotation } \\
\text { Growing a diverse number of crops in a } \\
\text { planned sequence in order to increase soil } \\
\text { organic matter and biodiversity in the soil }\end{array}$ & $\begin{array}{ll}\text { - } & \text { Increases nutrient cycling } \\
\text { - } & \text { Manages plant pests (weeds insects, and diseases) } \\
\text { - } & \text { Reduces sheet, rill, and wind erosion } \\
\text { - } & \text { - Adds diveril moisture } \\
& \text { Addy so soil microbes can thrive }\end{array}$ & $\begin{array}{l}\text { - Improves nutrient use efficiency } \\
\text { - Decreases use of pesticides } \\
\text { - } \quad \text { Improves water quality } \\
\text { Conserves water improves plant } \\
\text { production }\end{array}$ \\
\hline $\begin{array}{l}\text { Cover Crop } \\
\text { An un-harvested crop grown as part of } \\
\text { planned rotation to provide conservation } \\
\text { benefits to the soil. }\end{array}$ & $\begin{array}{ll}\text { - } & \text { Increases soil organic matter } \\
\text { - } & \text { Prevents soil erosion } \\
\text { - } & \text { Conserves soil moisture } \\
\text { - } & \text { Increases nutrient cycling } \\
\text { - } & \text { Provides nitrogen for plant use } \\
\text { - } & \text { Suppresses weeds } \\
\text { Reduces compaction }\end{array}$ & $\begin{array}{ll}\text { - } & \text { Improves crop production } \\
\text { - } & \text { Improves water quality } \\
\text { - } & \text { Improves water } \\
\text { - } & \text { Decreases use of pesticides } \\
\text { - } & \text { Improves water efficiency to crops }\end{array}$ \\
\hline $\begin{array}{l}\text { No Till } \\
\text { A way of growing crops without disturbing } \\
\text { the soil through tillage. }\end{array}$ & $\begin{array}{ll}\text { - } & \text { Improves water holding capacity of soils } \\
\text { - } & \text { Increases organic matter } \\
\text { - } & \text { Reduces soil erosion } \\
\text { - } & \text { Decreases compres use } \\
& \end{array}$ & $\begin{array}{ll}\text { - } & \text { Improves water efficiency } \\
\text { - } & \text { Conserves water } \\
\text { - } & \text { Improves crop production } \\
\text { - } & \text { Saves renewable resources } \\
\text { - } & \text { Improves air quality } \\
\text { - Increases productivity }\end{array}$ \\
\hline $\begin{array}{l}\text { Mulch Tillage } \\
\text { Using tillage methods where the soil surface } \\
\text { is disturbed but maintains a high level of } \\
\text { crop residue on the surface. }\end{array}$ & $\begin{array}{l}\text { - } \quad \text { Reduces soil erosion from wind and rain } \\
\text { - } \quad \text { Reduces soil moisture for plants } \\
\text { - } \quad \text { Increases soil organic matter }\end{array}$ & $\begin{array}{ll}\text { - } & \text { Improves water quality } \\
\text { - } & \text { Conserves wate } \\
\text { - } & \text { Improven renewable resources } \\
\text { - } & \text { Improves crop production }\end{array}$ \\
\hline $\begin{array}{l}\text { Mulching } \\
\text { Applying plant residues or other suitable } \\
\text { materials to the soil surface to compensate } \\
\text { for loss of residue due to excessive tillage. }\end{array}$ & 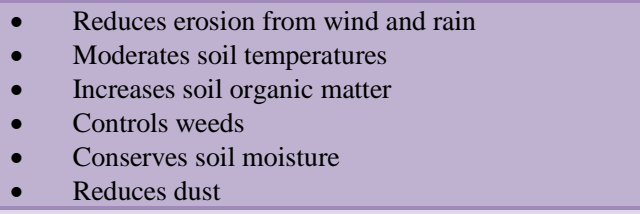 & $\begin{array}{ll}\text { - } & \text { Improves water quality } \\
\text { - } & \text { Improves plant productivity } \\
\text { - } & \text { Reduces pesticide usage } \\
\text { - } & \text { Conserves water } \\
\text { - } & \text { Improves air quality }\end{array}$ \\
\hline $\begin{array}{l}\text { Nutrient Management } \\
\text { Managing soil nutrients to meet crop needs } \\
\text { while minimizing the impact on the } \\
\text { environment and the soil. }\end{array}$ & $\begin{array}{l}\text { - Increases plant nutrient uptake } \\
\text { - Improves the physical, chemical, and biological } \\
\text { properties of the soil } \\
\text { - } \quad \text { Budgets, supplies, and conserves nutrients for } \\
\text { - } \quad \text { Reduces odors and nitrogen emissions }\end{array}$ & $\begin{array}{ll}\text { - } & \text { Improves water quality } \\
\text { - } & \text { Improves plant production } \\
& \text { Improves air quality }\end{array}$ \\
\hline $\begin{array}{l}\text { Pest Management } \\
\text { Managing pests by following an ecological } \\
\text { approach that promotes the growth of } \\
\text { healthy plants with strong defenses while } \\
\text { increasing stress on pests and enhancing the } \\
\text { habitat for beneficial organisms. }\end{array}$ & $\begin{array}{l}\text { - } \\
\text { - } \\
\text { - } \\
\text { Deduces pesticide risks to wates of chemicals entering the air } \\
\text { beneficial organisms } \\
\text { - Increases soil organic matter }\end{array}$ & $\begin{array}{ll}\text { - } & \text { Improves water quality } \\
\text { - } & \text { Improves air quality } \\
\text { - } & \text { Increases plant pollination } \\
\text { Increases plant productivity }\end{array}$ \\
\hline
\end{tabular}


Table.5 Distribution of soil organic carbon storage in water-stable aggregates in different soil layers and tillage treatments [Zheng et al., 2018]

\begin{tabular}{|c|c|c|c|c|c|c|c|c|c|}
\hline \multirow[t]{2}{*}{ Depth $(\mathrm{cm})$} & \multirow[t]{2}{*}{ Treatments } & \multicolumn{4}{|c|}{ Macro-aggregate $\left(\mathrm{t} \mathrm{ha}^{-1}\right)$} & \multicolumn{4}{|c|}{ Micro-aggregate ( $\left(\right.$ ha $\left.^{-1}\right)$} \\
\hline & & $>2 \mathrm{~mm}$ & $2-1 \mathrm{~mm}$ & $1-0.25 \mathrm{~mm}$ & Sum & $0.25-0.053 \mathrm{~mm}$ & $0.053-0.002 \mathrm{~mm}$ & $<0.002 \mathrm{~mm}$ & Sum \\
\hline \multirow[t]{4}{*}{$0-10$} & ST & $2.65 \pm 0.74 \mathrm{a}^{9}$ & $5.87 \pm 0.34 \mathrm{a}$ & $7.75 \pm 0.23 \mathrm{a}$ & $16.28 \pm 0.85 \mathrm{a}$ & $1.38 \pm 0.11 \mathrm{c}$ & $0.26 \pm 0.02 c$ & $0.26 \pm 0.08 b$ & $1.90 \pm 0.08 \mathrm{c}$ \\
\hline & NT & $1.40 \pm 0.07 \mathrm{~b}$ & $5.82 \pm 0.36 \mathrm{a}$ & $7.78 \pm 0.40 \mathrm{a}$ & $15.00 \pm 0.11 \mathrm{a}$ & $1.26 \pm 0.10 c$ & $0.23 \pm 0.02 c$ & $0.25 \pm 0.04 \mathrm{~b}$ & $1.75 \pm 0.08 c$ \\
\hline & MP & $0.35 \pm 0.01 \mathrm{~b}$ & $3.98 \pm 0.29 \mathrm{~b}$ & $5.91 \pm 0.43 \mathrm{~b}$ & $10.24 \pm 0.17 \mathrm{~b}$ & $2.44 \pm 0.06 \mathrm{~b}$ & $0.73 \pm 0.05 b$ & $0.69 \pm 0.07 \mathrm{a}$ & $3.86 \pm 0.08 b$ \\
\hline & CT & $0.44 \pm 0.04 \mathrm{~b}$ & $4.43 \pm 0.22 \mathrm{~b}$ & $6.11 \pm 0.54 \mathrm{~b}$ & $10.99 \pm 0.37 \mathrm{~b}$ & $2.88 \pm 0.08 \mathrm{a}$ & $1.96 \pm 0.23 \mathrm{a}$ & $0.44 \pm 0.14 \mathrm{ab}$ & $5.28 \pm 0.20 \mathrm{a}$ \\
\hline \multirow[t]{4}{*}{$10-20$} & ST & $2.43 \pm 0.03 \mathrm{a}$ & $6.85 \pm 0.19 \mathrm{a}$ & $9.14 \pm 0.16 \mathrm{ab}$ & $18.42 \pm 0.29 \mathrm{a}$ & $0.61 \pm 0.01 \mathrm{ab}$ & $1.54 \pm 0.10 c$ & $0.72 \pm 0.01 \mathrm{ab}$ & $2.86 \pm 0.11 \mathrm{~b}$ \\
\hline & NT & $1.62 \pm 0.02 \mathrm{~b}$ & $5.04 \pm 0.25 \mathrm{~b}$ & $8.49 \pm 0.10 \mathrm{~b}$ & $15.15 \pm 0.22 \mathrm{~b}$ & $0.49 \pm 0.10 \mathrm{~b}$ & $1.40 \pm 0.03 c$ & $0.67 \pm 0.14 \mathrm{~b}$ & $2.56 \pm 0.27 \mathrm{~b}$ \\
\hline & MP & $0.59 \pm 0.03 \mathrm{~d}$ & $4.02 \pm 0.31 \mathrm{C}$ & $7.67 \pm 0.3 \mathrm{lc}$ & $12.28 \pm 0.16 \mathrm{c}$ & $0.82 \pm 0.01 \mathrm{a}$ & $3.27 \pm 0.06 \mathrm{~b}$ & $0.97 \pm 0.02 \mathrm{ab}$ & $5.05 \pm 0.07 \mathrm{a}$ \\
\hline & $\mathrm{CT}$ & $1.35 \pm 0.09 \mathrm{c}$ & $4.69 \pm 0.09 b c$ & $9.42 \pm 0.19 \mathrm{a}$ & $15.46 \pm 0.36 \mathrm{~b}$ & $0.73 \pm 0.11 \mathrm{ab}$ & $3.56 \pm 0.08 \mathrm{a}$ & $1.05 \pm 0.17 \mathrm{a}$ & $5.35 \pm 0.23 \mathrm{a}$ \\
\hline \multirow[t]{4}{*}{$20-30$} & ST & $3.06 \pm 0.10 \mathrm{a}$ & $6.77 \pm 0.51 \mathrm{a}$ & $9.92 \pm 0.17 \mathrm{a}$ & $19.75 \pm 0.47 \mathrm{a}$ & $1.70 \pm 0.56 \mathrm{a}$ & $0.96 \pm 0.28 \mathrm{~b}$ & $0.21 \pm 0.11 \mathrm{c}$ & $2.87 \pm 0.44 \mathrm{~b}$ \\
\hline & NT & $1.41 \pm 0.03 \mathrm{~b}$ & $6.32 \pm 0.47 \mathrm{a}$ & $8.30 \pm 0.10 \mathrm{ab}$ & $16.02 \pm 0.34 \mathrm{c}$ & $1.99 \pm 0.13 \mathrm{a}$ & $0.98 \pm 0.10 \mathrm{~b}$ & $0.54 \pm 0.11 b x$ & $3.51 \pm 0.32 \mathrm{~b}$ \\
\hline & MP & $2.15 \pm 0.26 b$ & $6.52 \pm 1.23 \mathrm{a}$ & $9.03 \pm 1.10 \mathrm{ab}$ & $17.71 \pm 0.38 \mathrm{~b}$ & $2.03 \pm 0.22 \mathrm{a}$ & $0.59 \pm 0.21 \mathrm{~b}$ & $0.59 \pm 0.06 \mathrm{~b}$ & $3.20 \pm 0.37 \mathrm{~b}$ \\
\hline & $\mathrm{CT}$ & $2.09 \pm 0.46 b$ & $3.48 \pm 0.36 \mathrm{~b}$ & $7.76 \pm 0.11 \mathrm{~b}$ & $13.33 \pm 0.07 \mathrm{~d}$ & $1.88 \pm 0.07 \mathrm{a}$ & $1.73+0.09 \mathrm{a}$ & $2.12 \pm 0.14 a$ & $5.73 \pm 0.06 a$ \\
\hline \multirow[t]{4}{*}{$30-40$} & ST & $1.92 \pm 0.03 \mathrm{a}$ & $5.74 \pm 0.61 \mathrm{a}$ & $7.01 \pm 0.57 \mathrm{a}$ & $14.67 \pm 0.09 \mathrm{a}$ & $1.29 \pm 0.26 \mathrm{a}$ & $0.68 \pm 0.24 \mathrm{a}$ & $0.33 \pm 0.04 a$ & $2.31 \pm 0.10 \mathrm{a}$ \\
\hline & NT & $1.06 \pm 0.25 \mathrm{ab}$ & $4.00 \pm 0.54 \mathrm{a}$ & $4.43 \pm 0.15 b$ & $9.50 \pm 0.34 \mathrm{~b}$ & $1.27 \pm 0.15 \mathrm{a}$ & $0.93 \pm 0.34 \mathrm{a}$ & $0.26 \pm 0.10 \mathrm{a}$ & $2.45 \pm 0.27 \mathrm{a}$ \\
\hline & MP & $1.12 \pm 0.45 \mathrm{ab}$ & $4.71 \pm 0.42 \mathrm{a}$ & $7.72 \pm 0.57 \mathrm{a}$ & $13.56 \pm 0.23 \mathrm{a}$ & $1.20 \pm 0.06 \mathrm{a}$ & $0.56 \pm 0.14 \mathrm{a}$ & $0.31 \pm 0.12 \mathrm{a}$ & $2.07 \pm 0.12 \mathrm{a}$ \\
\hline & $\mathrm{CT}$ & $0.60 \pm 0.14 \mathrm{~b}$ & $2.87 \pm 1.53 \mathrm{a}$ & $5.83 \pm 1.19 \mathrm{ab}$ & $9.30 \pm 1.01 \mathrm{~b}$ & $2.00 \pm 0.58 \mathrm{a}$ & $0.95 \pm 0.26 \mathrm{a}$ & $0.10 \pm 0.02 \mathrm{a}$ & $3.05 \pm 0.86 a$ \\
\hline \multirow[t]{4}{*}{$40-50$} & ST & $0.66 \pm 0.23 \mathrm{ab}$ & $3.29 \pm 0.90 \mathrm{a}$ & $4.60 \pm 0.55 \mathrm{a}$ & $8.55 \pm 0.39 \mathrm{a}$ & $0.79 \pm 0.35 \mathrm{a}$ & $0.48 \pm 0.18 \mathrm{a}$ & $0.26 \pm 0.06 \mathrm{a}$ & $1.53 \pm 0.58 \mathrm{a}$ \\
\hline & $\mathrm{NT}$ & $0.23 \pm 0.07 \mathrm{~b}$ & $1.66 \pm 0.24 \mathrm{a}$ & $4.02 \pm 0.36 \mathrm{ab}$ & $5.90 \pm 0.23 \mathrm{c}$ & $1.09 \pm 0.26 \mathrm{a}$ & $0.16 \pm 0.04 a$ & $0.21 \pm 0.06 \mathrm{a}$ & $1.46 \pm 0.35 \mathrm{a}$ \\
\hline & MP & $0.87 \pm 0.24 \mathrm{a}$ & $2.97 \pm 0.60 \mathrm{a}$ & $3.35 \pm 0.26 \mathrm{~b}$ & $7.18 \pm 0.27 \mathrm{~b}$ & $0.93 \pm 0.16 \mathrm{a}$ & $0.25 \pm 0.19 \mathrm{a}$ & $0.34 \pm 0.07 \mathrm{a}$ & $1.53 \pm 0.26 a$ \\
\hline & CT & $0.55 \pm 0.19 \mathrm{ab}$ & $1.71 \pm 0.20 \mathrm{a}$ & $4.85 \pm 0.04 \mathrm{a}$ & $7.11 \pm 0.33 \mathrm{~b}$ & $1.35 \pm 0.29 \mathrm{a}$ & $0.33 \pm 0.11 \mathrm{a}$ & $0.15 \pm 0.06 a$ & $1.83 \pm 0.27 \mathrm{a}$ \\
\hline \multirow[t]{4}{*}{$50-60$} & ST & $0.23 \pm 0.15 \mathrm{a}$ & $1.99 \pm 0.21 \mathrm{a}$ & $3.48 \pm 0.31 \mathrm{a}$ & $5.69 \pm 0.05 a$ & $0.80 \pm 0.04 b$ & $0.22 \pm 0.04 \mathrm{~b}$ & $0.33+0.06 \mathrm{a}$ & $1.34 \pm 0.12 \mathrm{~b}$ \\
\hline & NT & $0.34 \pm 0.07 \mathrm{a}$ & $1.06 \pm 0.06 \mathrm{~b}$ & $3.50 \pm 0.17 \mathrm{a}$ & $490 \pm 0.06 \mathrm{~b}$ & $1.33 \pm 0.08 \mathrm{a}$ & $0.19 \pm 0.04 \mathrm{~b}$ & $0.17 \pm 0.03 \mathrm{a}$ & $1.69 \pm 0.10 b$ \\
\hline & $\mathrm{MP}$ & $0.31 \pm 0.11 \mathrm{a}$ & $2.21 \pm 0.25 \mathrm{a}$ & $3.20 \pm 0.35 \mathrm{ab}$ & $5.72 \pm 0.14 \mathrm{a}$ & $1.29 \pm 0.03 \mathrm{a}$ & $0.20 \pm 0.06 \mathrm{~b}$ & $0.23 \pm 0.07 \mathrm{a}$ & $1.71 \pm 0.15 b$ \\
\hline & $\mathrm{CI}$ & $0.15 \pm 0.03 \mathrm{a}$ & $1.83 \pm 0.10 \mathrm{a}$ & $2.38 \pm 0.06 \mathrm{~b}$ & $4.36 \pm 0.05 c$ & $1.21 \pm 0.02 a$ & $0.96 \pm 0.06 a$ & $0.26 \pm 0.04 a$ & $2.44 \pm 0.12 \mathrm{a}$ \\
\hline
\end{tabular}

Fig.1 Estimates of decomposition rates of SOC components [Source: Bell and Lawrence, 2009]
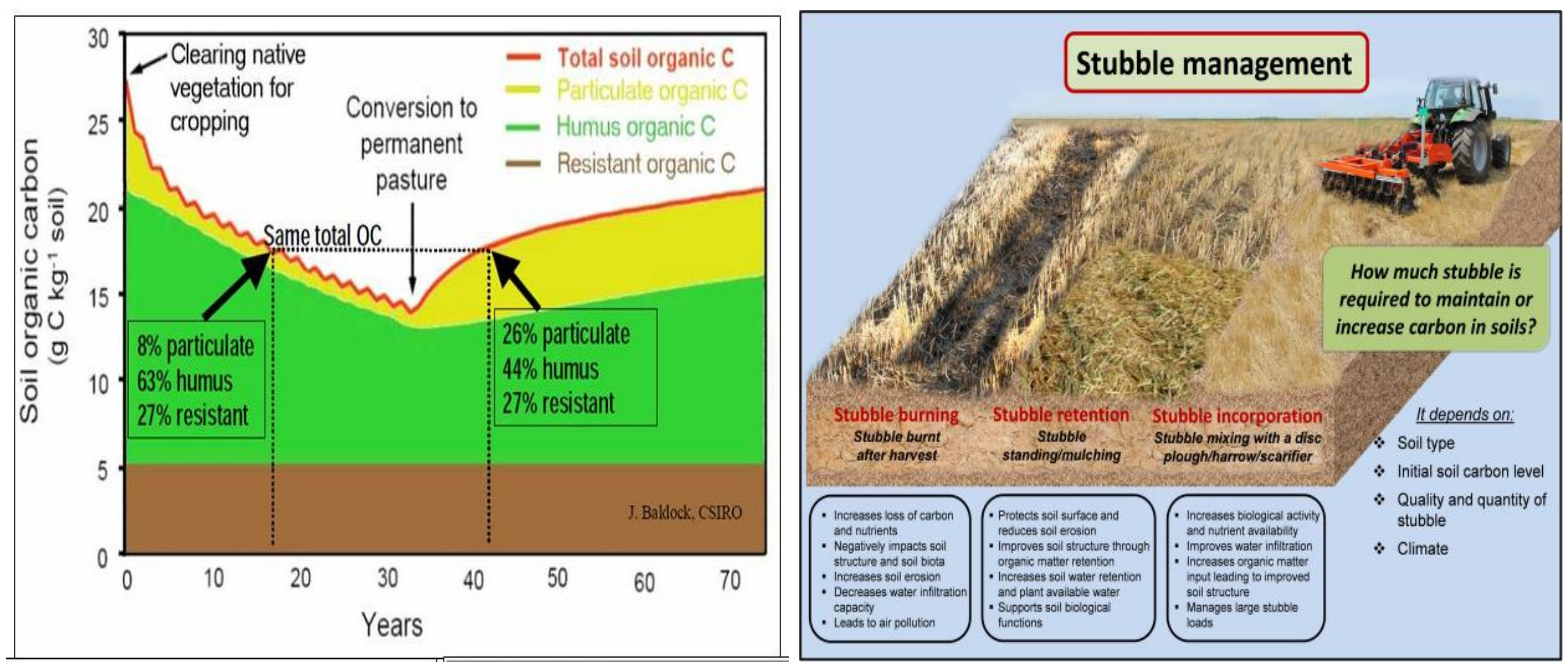
Fig.2a\&b Chemical, biological, and physical benefits in soil to which soil organic carbon (SOC) contributes [Source:Carson, 2013]\&1(b): The influence of soil type, climate and management factors on the storage of organic carbon (OC) that can be achieved in a given soil

[Source: Ingram and Fernandes, 2001]

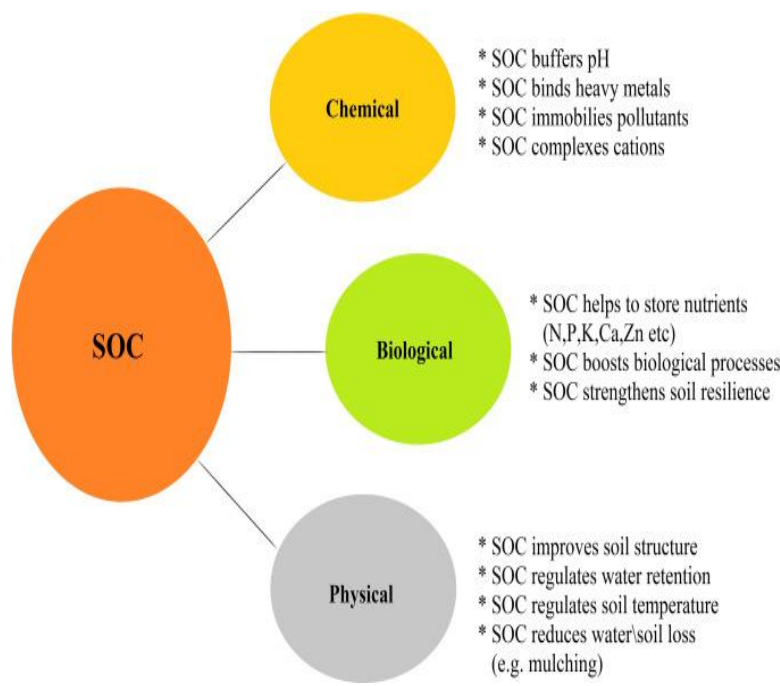

(a)

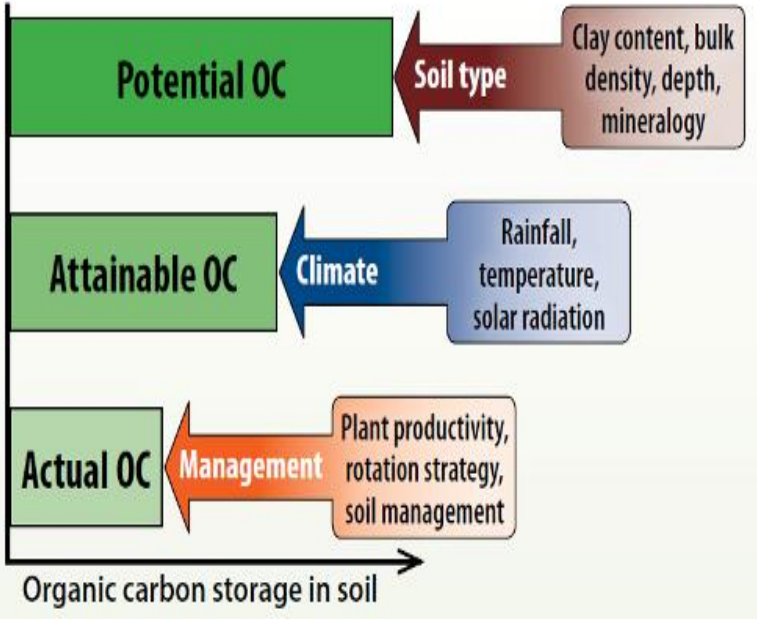

(b)

Fig.3a\&b Simulated soil C stocks at 0-0.3 m layer in sugarcane areas under green management, straw removal, and best management practices. [Source: Oliveira et al., 2017] \& 2 (b): Impacts of crop residue management on soil functions and plant growth [Source: Stavi et al., 2016]

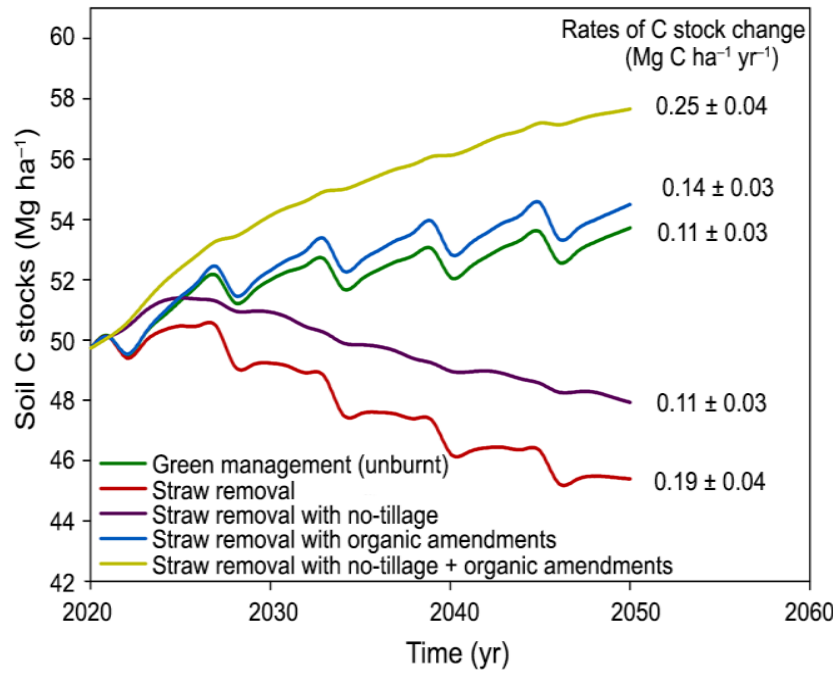

(a)

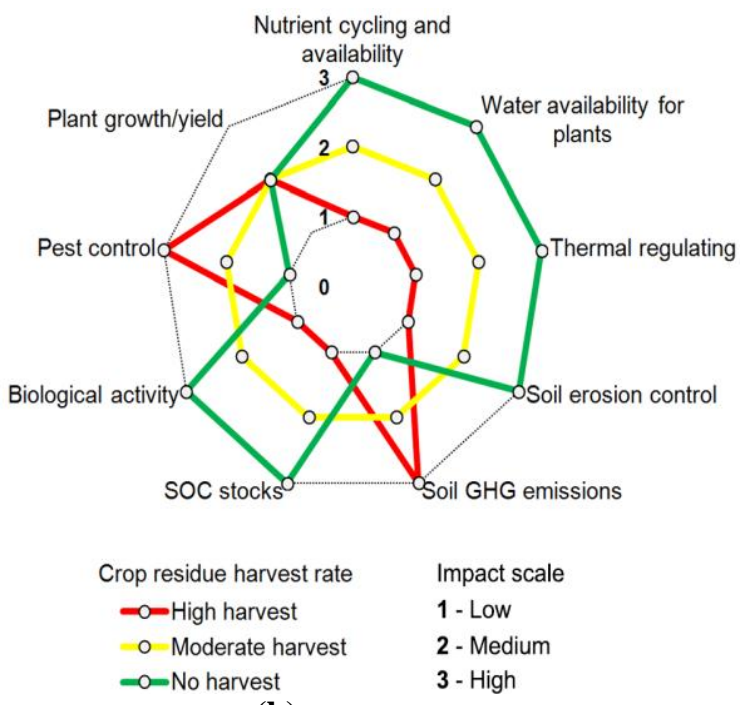

(b) 
Fig.4a\&b Sources and sinks of carbon from different pools under terrestrial and aquatic ecosystems [Source: Mehra et al., 2018] \& 3(b): Effect of soil quality indicators on the rhizospheric soil [Source: Thornton et al., 2014]

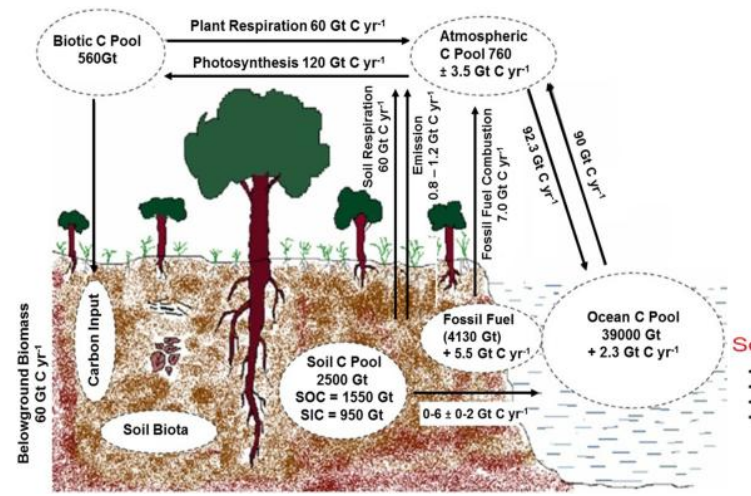

(a)

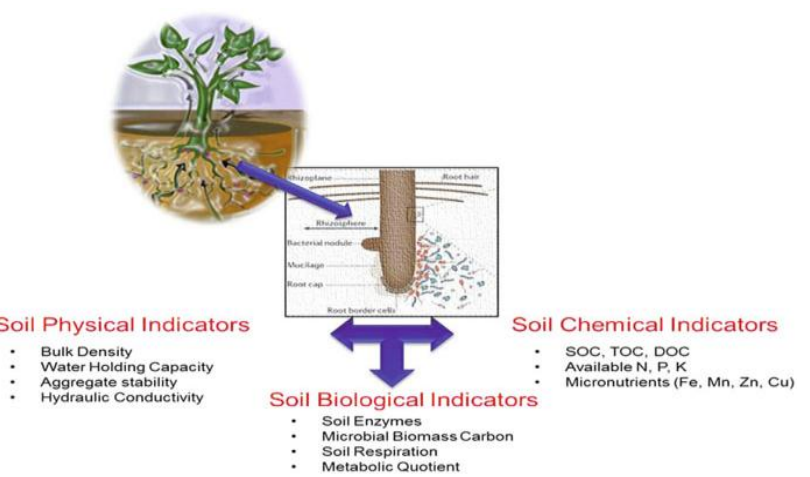

(b)

Fig.5a\&b How microbes increase soil nutrient availability and build soil organic matter \& 5(b): Different fractions of soil organic matter decompose in the soil over different time frames

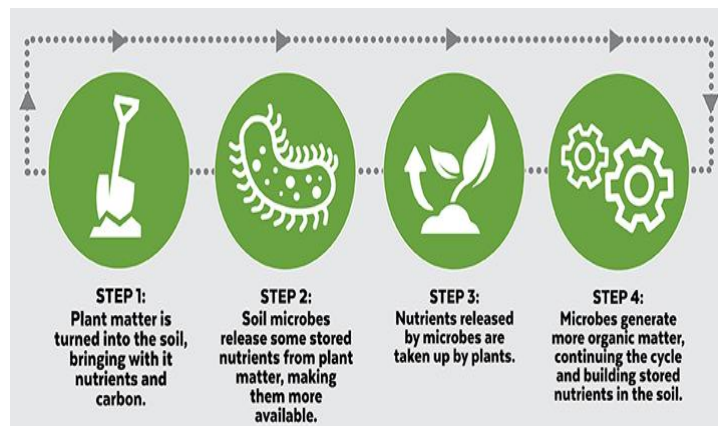

(a)

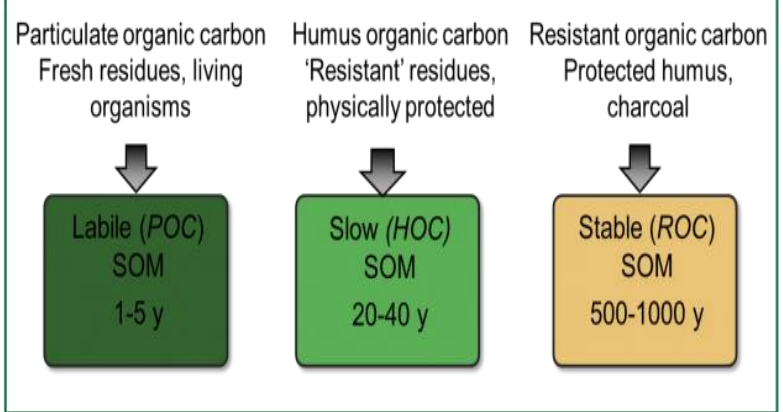

(b)

Fig.6a\&b Role of microbial biomass in the cycling of nutrients in rhizosphere [Source: Doran et al., 1996] \& 6(b): Abiotic and biotic factors constituting soil quality in the soils of the world

(modified from Brussaard (2012)

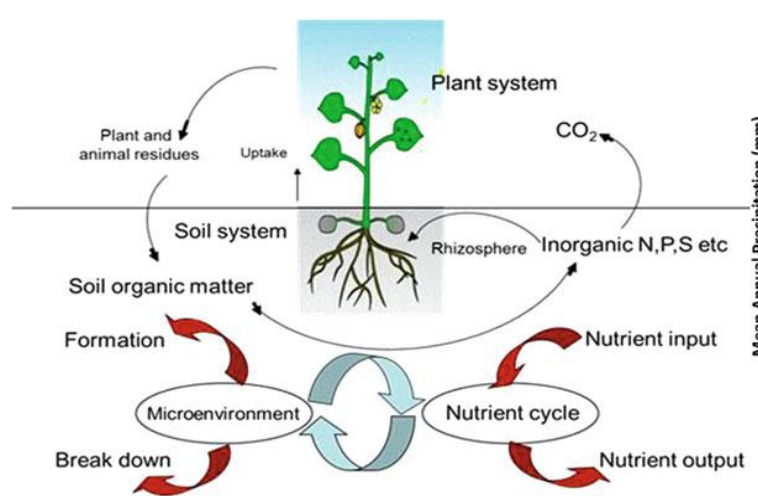

(a)

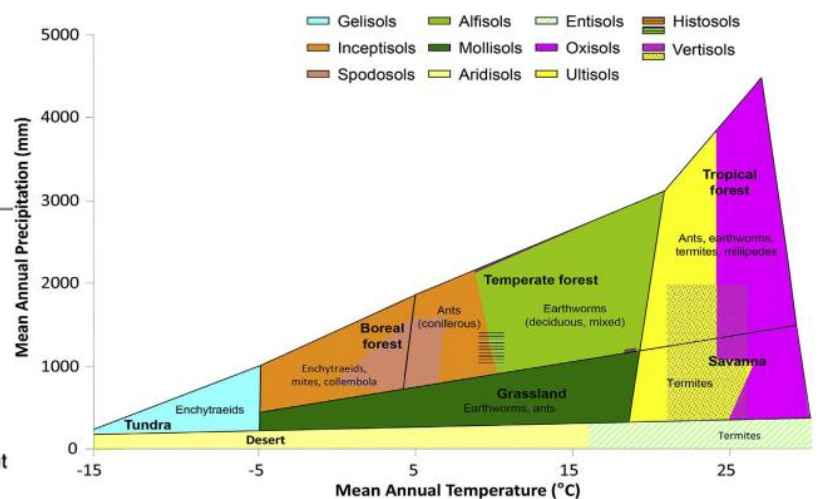

(b) 
Fig.7a\&b\&c Soil organic carbon by depth after 9 years of no-till, ridge-till or plow-till treatment [Source: Zibilsk et al., 2002]; 7(b): Readily oxidizable soil carbon by depth after 9 years of notill, ridge-till or plow-till treatment [Source: Zibilsk et al., 2002] \& 7(c): Total soil nitrogen by depth after 9 years of no-till, ridge-till or plow-till treatment [Source: Zibilsk et al., 2002]

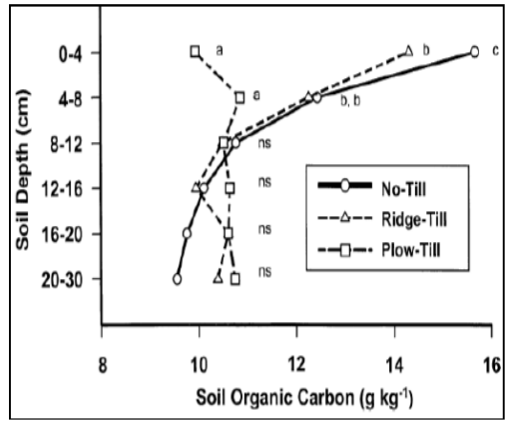

(a)

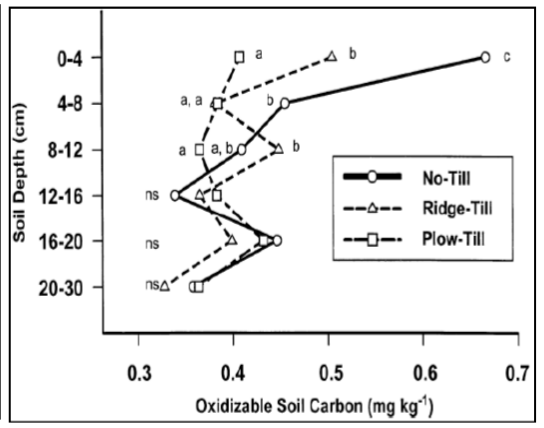

(b)

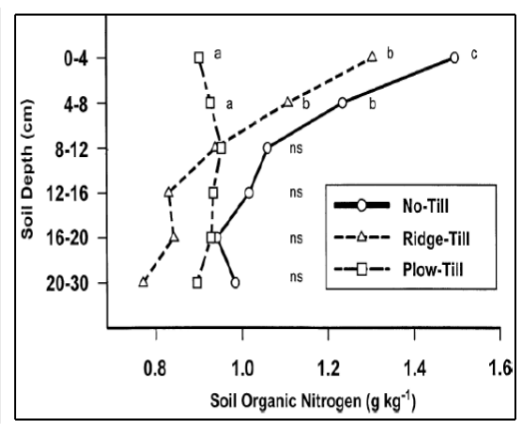

(c)

Fig.8a\&b\&c Effects of cropping on soil properties and organic carbon stock [source: Mandal et al., 2012]; 8(b): Effects of fertilization on soil microbial biomass $\mathrm{C}$ and $\mathrm{N}$ and soluble organic $\mathrm{C}$ and N [Source: Liang et al., 2011] \& 8(c): Influence of different tillage intensities on soil microbial biomass at different depths (Source: Murugan et al., 2013]

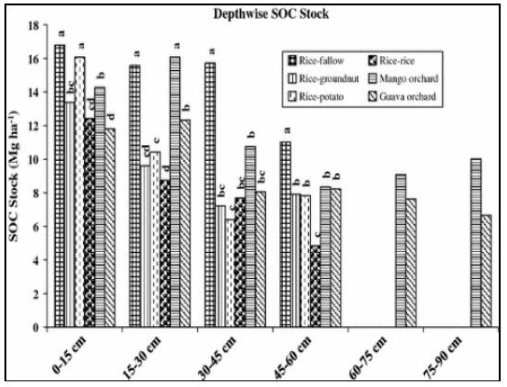

(a)

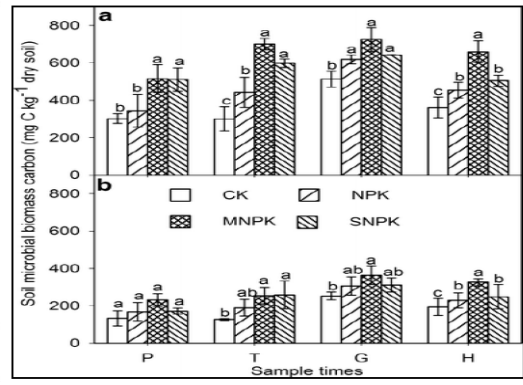

(b)

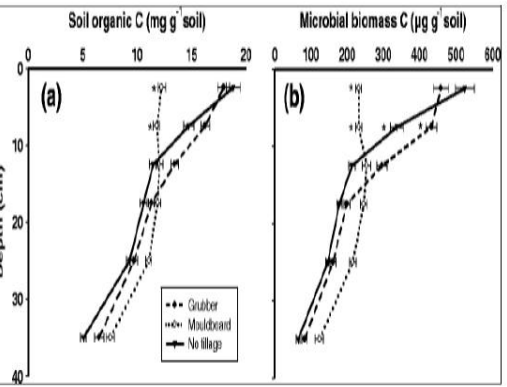

(c)

Fig.9a\&b\&c Total C, N, and microbial biomass $\mathrm{C}$ and $\mathrm{N}$ depending on land use and depth [Source: Maharjan et al., 2017]; 9(b): Conceptual diagram representing the effect of land use on carbon and nitrogen content in soil along with enzyme activities [Source: Maharjan et al., 2017]\& 9(c): Activities of C-cycle enzymes: $\beta$-glucosidase, cellobiohydrolase and xylanase depending on land use and depth [Source: Maharjan et al., 2017]

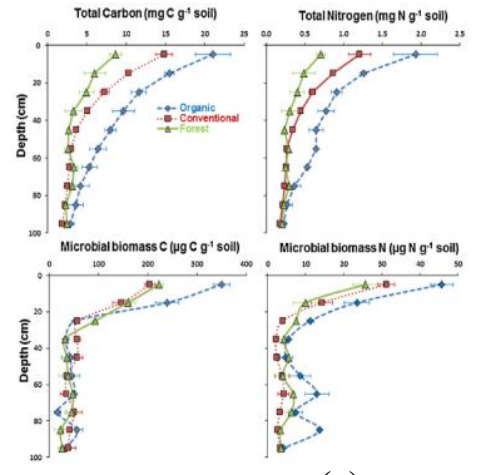

(a)

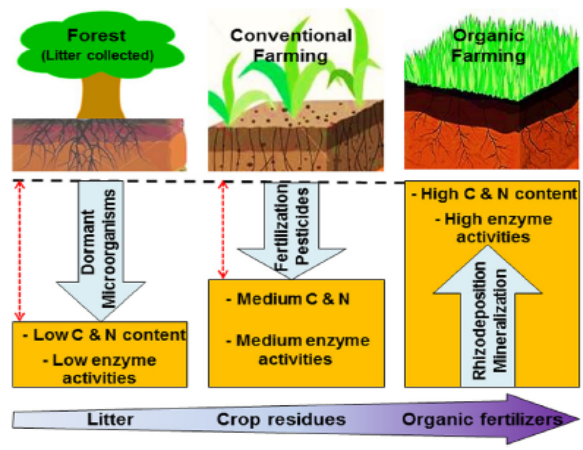

(b)

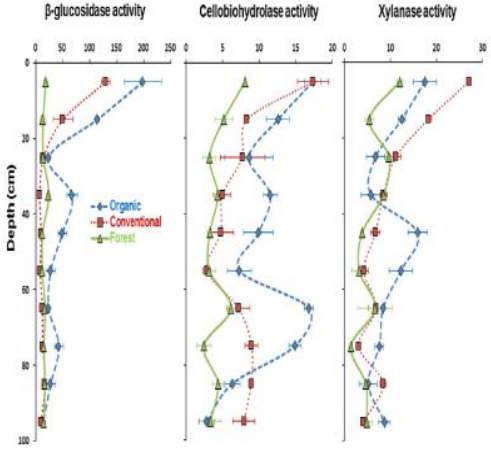

(c) 
Fig.10a\&b\&c Soil microbial biomass carbon and nitrogen (SMBC, SMBN) in Ferralic Cambisol, Calcaric Cambisol, and Luvic Phaeozem at the end of 1st and 12th months with the amendment of different organic materials [Source: Li et al., 2018] \& 10(b): Change in POM-C

d13C in different treatments for 0e10 cm (A) and 10-30 cm (B) depth from 2008 to 2014 [Source: Kantola et al., 2017] 10(c): SOC content in the different biofuel crops and prairie soils from 2008 to 2014 Figure 1A shows the 0-10 cm depth, while Figure 1B shows the 10-30 cm depth. Maize was alternated with soybean in 2010 and 2013 [Source: Kantola et al., 2017].

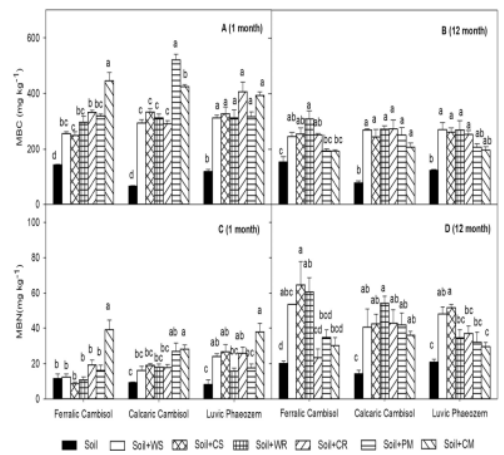

(a)

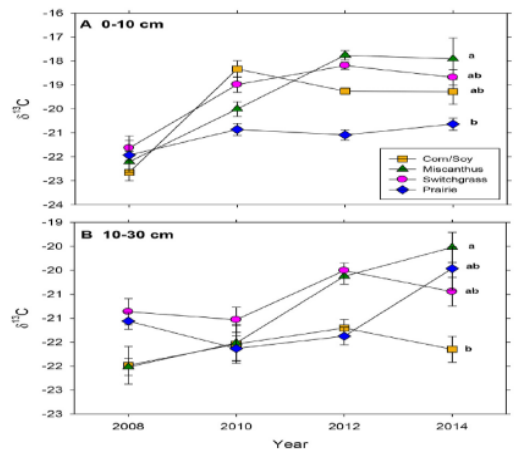

(b)

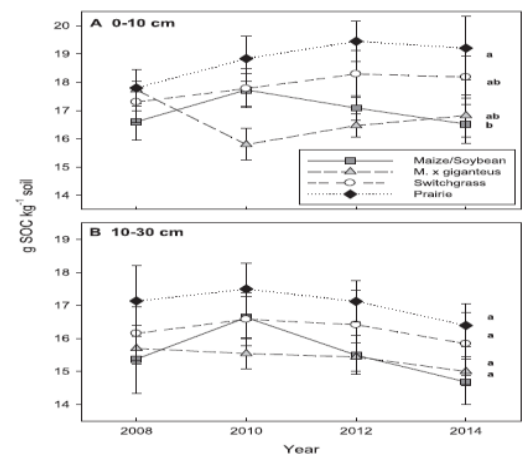

(c)

Fig.11a\&b\&c Influence of different tillage intensities on soil microbial biomass at different depths (Source: Murugan et al., 2013]11(b): Distribution of (a) microbial biomass C (MBC), (b) permanganate oxidizable $\mathrm{C}$ (POX-C), (c) cold-water extractable organic $\mathrm{C}$ (CWEOC) and (d) hot-water extractable organic $\mathrm{C}$ (HWEOC) as affected by different land use systems [Source: Geraei et al., 2016]11(c): Microbial biomass carbon (MBC) (a) and the Cmic: Corg ratios (b) of the three sizes of soil aggregates and bulk soil of different land uses [Source: Xiao et al., 2016]

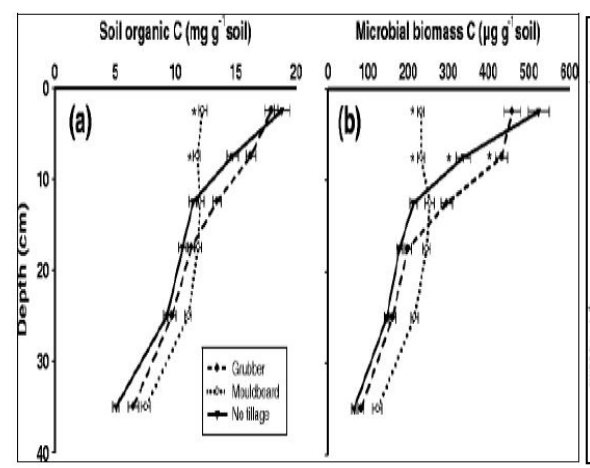

(a)

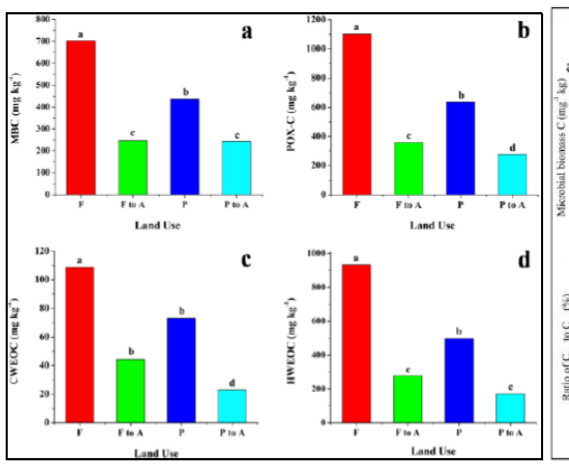

(b)

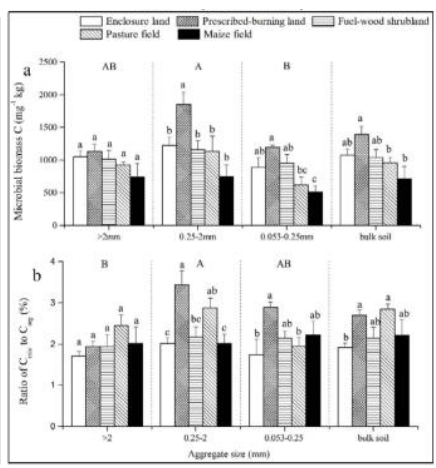

(c)
The corresponding increase of PON content under CA system was from 35.9 mgkg-1 in CT system to 49 and $69.6 \mathrm{mgkg}^{-1}$ without CR and 79.3, 93.0 and $104.3 \mathrm{mgkg}^{-1}$ with CR @ 2, 4 and 6 tha $^{-1}$, respectively. Small improvement in PON content was observed after 4 years of the experiment. Singh et al., (2014) found that carbon stock of 18.75 , 19.84 and $23.83 \mathrm{Mg} \mathrm{ha}^{-1}$ in the surface $0.4 \mathrm{~m}$ soil depth observed under CT was increased to $22.32,26.73$ and $33.07 \mathrm{Mg} \mathrm{ha}^{-1}$ in 15 years of ZT in sandy loam, loam and clay loam soil. This increase was highest in clay loam (38.8\%) followed by loam (34.7\%) and sandy loam $(19.0 \%)$ soil. The carbon sequestration rate was found to be $0.24,0.46$ and $0.62 \mathrm{Mg}$ $\mathrm{ha}^{-1} \mathrm{yr}^{-1}$ in sandy loam, loam and clay loam soil under ZT over CT. Thus, fine textured 
soils have more potential for storing carbon and ZT practice enhances carbon sequestration rate in soils by providing better conditions in terms of moisture and temperature for higher biomass production and reduced oxidation (Gonzalez-Sanchez et al., 2012). Gupta Choudhury et al., (2014) revealed that the residue incorporation or retention caused a significant increment of $15.65 \%$ in total water stable aggregates in surface soil $(0-15 \mathrm{~cm})$ and $7.53 \%$ in subsurface soil $(15-30 \mathrm{~cm})$, which depicted that residue management could improve 2.1-fold higher water stable aggregates as compared to the other treatments without residue incorporation/retention. Bhattacharya et al., (2013) reported that tillage-induced changes in POM C were distinguishable only in the 0to $5-\mathrm{cm}$ soil layer; the differences were insignificant in the 5 to $15-\mathrm{cm}$ soil layer. Plots under ZT had about 14\% higher POM C than CT plots (3.61 $\mathrm{g} \mathrm{kg}^{-1}$ bulk soil) in the surface soil layer.

In conclusion, soil microbial biomass, the active fraction of soil organic matter which plays a central role in the flow of $\mathrm{C}$ and $\mathrm{N}$ in ecosystems responds rapidly to management practices, and serves as an index of soil fertility. The practices of crop residue retention and tillage reduction provided an increased supply of $\mathrm{C}$ and $\mathrm{N}$ which was reflected in terms of increased levels of microbial biomass, $\mathrm{N}$-mineralization rate in soil. Organic and regenerative agriculture can remove carbon dioxide from the atmosphere and sequester it in the soil. Conversion of the world's crops to organic production could trap 5-24\% of annual carbon dioxide releases in the soil. Incorporation of cover crops, composts, and reduced tillage methods into conventional agriculture could improve soil structure, and reduce synthetic fertilizers and pesticides. Organic management of pastures and livestock could remove an additional 13\% to $74 \%$ of yearly greenhouse gas emissions.
Conservatively, regenerative agriculture techniques could reduce green- house gases by at least $17 \%$ each year. These reductions are possible, and we should implement them before it is too late. Crop residue retention also slightly altered the composition of microbial communities. Furthermore, the adoption of conservation agriculture practices resulted in 53\%-85\% greater cumulative mineralization of $\mathrm{C}$. This study suggests that the application of straw is a long-term effective measure to increase microbial biomass, and can further induce the changes of soil properties to regulate soil microbial community.

\section{References}

Amaranthus, M., and Allyn, B. 2013. Healthy Microbes, Healthy People. The Atlantic. June 11, 2013.

Aulakh, M.S., Garg, A. K., and Kumar, Shrvan. 2013. Impact of Integrated Nutrient, Crop Residue and Tillage Management on Soil Aggregates and Organic Matter Fractions in Semiarid Subtropical Soil under Soybean-Wheat Rotation. Am. J Plant Sci., 4:2148-2164.

Bhattacharyya, R., Pandey, S.C., Bisht, J.K., Bhatt, J.C., Gupta, H.S., Tuti, M.D., et al., 2013. Tillage and Irrigation Effects on Soil Aggregation and Carbon Pools in the Indian Sub-Himalayas. Agro J. 105(1):101-112

Blouin, M., Hodson, M.E., Delgado, E.A., Baker, G., Brussaard, L., Butt, K.R., Dai, J., Dendooven, L., Peres, G., Tondoh, J.E., Cluzeau, D., and Brun, J.J. 2013. A review of earthworm impact on soil function and ecosystem services. European JSoil Sci, 64(2): 161-182.

Bot, A., and Benites, J. 2005. The importance of soil organic matter. FAO Soils Bulletin. Food and Agriculture Organization of the United Nations. 
Brussaard, L. 2012. Ecosystem Services Provided by the Soil Biota. in: Soil Ecology and Ecosystem Services, (Eds.) D.H. Wall, R.D. Bardgett, V. BehanPelletier, J.E. Herrick, H. Jones, K. Ritz, J. Six, D.R. Strong, W.H. van der Putten, Oxford University Press. Oxford, UK, pp. 45-58.

Brussaard, L., Kuyper, T.W., Didden, W.A.M., de Goede, R.G.M., and Bloem, J. 2004. Biological soil quality from biomass to biodiversity importance and resilience to management stress and disturbance. in: Managing soil quality: challenges in modern agriculture, (Eds.) P. Schjoenning, S. Elmholt, B.T. Christensen, CABI. Wallingford, UK, pp. 139-171.

Cardinael, R., Guenet, B., Chevallier, T., Dupraz, C., Cozzi, T., and Chenu, C. 2018. High organic inputs explain shallow and deep SOC storage in a long-term agro-forestry system combining experimental and modeling approaches. Biogeosci. 15:297-317.

Cardoso, E.J.B.N., Figueiredo Vasconcellos, R.L., Bini, D., Horta Miyauchi, M.Y., dos Santos, C.A., Lopes Alves, P.R., de Paula, A.M., Nakatani, A.S., Pereira, J.d.M., and Nogueira, M.A. 2013. Soil health: looking for suitable indicators. What should be considered to assess the effects of use and management on soil health? Scientia Agricola, 70(4): 274289.

Carson, J. 2013. How much carbon can soil store? New South Wales Department of Primary Industries, New South Wales (2013)

Cookson, W.E., Murphy, D.V., and Roper, M.M. 2008.Characterizing the relationships between soil organic matter components and microbial function and composition along a tillage disturbance gradient. Soil Biol Biochem
40: 763-777.

Coyle, C., Creamer, R.E., Schulte, R.P.O., O'Sullivan, L., and Jordan, P. 2016. A Functional Land Management conceptual framework under soil drainage and land use scenarios. Environ. Sci. Policy 56: 39-48.

Doran, J.W., Sarrantonio, M., and Lieberg, M.A. 1996. Soil health and sustainability. In: Sparks DL (ed) Adv Agron, 56:1-54

Edenhofer, O., R. Pichs-Madruga, Y. Sokona et al., eds. Climate Change 2014: Mitigation of Climate Change. Fifth Assessment Report of the Intergovernmental Panel on Climate Change (IPCC). Cambridge University Press. pp. 811-922.

Franzluebbers, A.J. 2015. Farming strategies to fuel bioenergy demands and facilitate essential soil services. Geoderma 259260: 251-258.

Fereres, E., Orgaz, F., Gonzalez-Dugo, V., Testi, L.; and Villalobos, F.J. 2014. Balancing crop yield and water productivity tradeoffs in herbaceous and woody crops. Funct. Plant Biol. 41: 1009-1018

Foissner, W. 1999. Soil protozoa as bioindicators: pros and cons, methods, diversity, representative examples. Agric. Ecosyst Environ, 74(1-3): 95112.

Ghaley, B., Vesterdal, L., and Porter, J.R. 2014. Quantification and valuation of ecosystem services in diverse production systems for informed decision-making. Environ. Sci. Policy 39: 139-149.

Geraei, D.S., Hojati, S., Landi, A., Cano, A.F. 2016.Total and labile forms of soil organic carbon as affected by land use change in southwestern Iran. Geoderma. 7:29-37.

Ghaley, B., Porter, J., and Sandhu, H.S. 2014. Soil-based ecosystem services: A 
synthesis of nutrient cycling and carbon sequestration assessment methods. Int. J. Biodivers. Sci. Ecosyst. Serv. Manag. 10: 177-186.

Gonzalez-Sanchez, E.J., Ordonez-Fernandez, R., Carbonell- Bojollo, R., VerozGonzalez, O., and Gil- Ribes, J.A. 2012. Meta-analysis on atmospheric carbon capture in Spain through the use of conservation agriculture. Soil Tillage Res.122:52-60.

Gupta Choudhury, Shreyasi., Sonal Srivastava, Ranbir Singh, Chaudhari,S.K., Sharma, D.K., et al., 2014.Tillage and residue management effects on soil aggregation, organic carbon dynamics and yield attribute in rice-wheat cropping system under reclaimed sodic soil. Soil Tillage Res. 136:76-83

Gupta, V., and Germida, J.J. 2015. Soil aggregation: Influence on microbial biomass and implications for biological processes. Soil Biol. Biochem. 80:A3A9.

Hobbs, P.R., Sayre, K., and Gupta, R. 2008. The role of conservation agriculture in sustainable agriculture. Philos. Trans. R. Soc. B Biol. Sci. 363: 543-555.

Holland, J.M. 2004. The environmental consequences of adopting conservation tillage in Europe: Reviewing the evidence. Agric. Ecosyst. Environ. 103: $1-25$.

Ingram, J.S.I., and Fernandes, E.C.M. 2001. Managing carbon sequestration in soils: Concepts and terminology, Agri.Ecosyst Environ, 87: 111-117.

Jiang, X., Wright, A.L., Wang, J., and Li, Z. 2011.Long-term tillage effects on the distribution patterns of microbial biomass and activities within soil aggregates. Catena. 87:276-280.

Kay, B.D., and Angers, D.A. 1999. Soil structure. M.E. Sumner) (Ed.), Handbook of soil science, CRC Press,
Boca Raton, USA (1999), pp. 229-276

Kertész, A., and Madarász, B. 2014. Conservation Agriculture in Europe. Int. Soil Water Conserv. Res. 2: 91-96.

Kantola, I.B., Masters, M.D., and DeLucia, E.H. 2017. Soil particulate organic matter increases under perennial bioenergy crop agriculture. Soil Biol Biochem. 113: 184-191.

Lal, R. 2000. Mulching effects on soil physical quality of an alfisol in western Nigeria. Land Degradation Development 11(4): 383-92.

Lal, R. 2004a. Soil carbon sequestration impacts on global climate change and food security. Science 304:1623-1627.

Lal, R. 2004b. Soil carbon sequestration to mitigate climate change. Geoderma 123:1-22.

Lavelle, P., Decaëns, T., Aubert, M., Barot, S., Blouin, M., Bureau, F., Margerie, P., Mora, P., and Rossi, J.P. 2006. Soil invertebrates and ecosystem services. European J Soil Biol, 42, Supplement 1(0): S3-S15.

Lehman, R.M., Cambardella, C.A., Stott, D.E., Acosta-Martinez, V., Manter, D.K., Buyer, J.S., Maul, J.E., Smith, J.L., Collins, H.P., Halvorson, J.J., Kremer, R.J., Lundgren, J.G., Ducey, T.F., Jin, V.L., and Karlen, D.L. 2015. Understanding and Enhancing Soil Biological Health: The Solution for Reversing Soil Degradation. Sustainability, 7(1): 988-1027.

Lemanceau, P., Creamer, R., and Griffiths, B.S. 2016. Soil biodiversity and ecosystem functions across Europe: A transect covering variations in biogeographical zones, land use and soil properties. Appl. Soil Ecol. 97: 1-2.

Li, L., Xu,M.,Eyakub, Ali. M., Zhang, W., Duan, Y., and Li, D. 2018. Factors affecting soil microbial biomass and functional diversity with the application of organic amendments in three 
contrasting cropland soils during a field experiment. PLoS ONE 13(9): e020381

Liang, B., Yang, X., He, X., and Zhou, J. 2011. Effects of 17-year fertilization on soil microbial biomass $\mathrm{C}$ and $\mathrm{N}$ and soluble organic $\mathrm{C}$ and $\mathrm{N}$ in loessial soil during maize growth. Biol. Fertility Soils. 47(2):121-128.

Maharjana, M., Sanaullaha, M., Razavid, B.S., and Kuzyakov, Y. 2017. Effect of land use and management practices on microbial biomass and enzyme activities in subtropical top-and subsoils. Appl Soil Ecol. 113: 22-28.

Malhi, S.S., Nyborg, M., Goddard, T., and Puurveen, D. 2011aLong-term tillage, straw and $\mathrm{N}$ rate effects on some chemical properties in two contrasting soil types in Western Canada. Nutr. Cycling Agro ecosyst. 90:133-146.

Mandal, K.G., Baral, U., Padhi, J.P., Majhi, P., Chakraborty, H., and Kumar, A. 2012. Effects of cropping on soil properties and organic carbon stock in Deras region, India. Reg. Environ. Change. 12(4): 899-912.

Maurício Roberto Cherubin, Dener Márcio da Silva Oliveira, Brigitte Josefine Feigl, Laisa Gouveia Pimentel, Izaias Pinheiro Lisboa, Maria Regina Gmach, Letícia Leal Varanda, Maristela Calvente Morais, Lucas Santos Satiro, Gustavo Vicentini Popin, Sílvia Rodrigues de Paiva, Arthur Klebson Belarmino dos Santos, Ana Luisa Soares de Vasconcelos, Paul Lineker Amaral de Melo, Carlos Eduardo Pellegrino Cerri, and Carlos Clemente Cerri. 2018. Crop residue harvest for bioenergy production and its implications on soil functioning and plant growth: A review, Sci. Agric. 75(3): 255-272.

McNear Jr., D. H. 2013. The rhizosphere roots, soil and everything in between. Nature Education Knowledge 4(30): 1

Mehra, P., Desbiolles, J., Baker, J., Sojka, R.
E., Bolan, N., Kirkham, M. B., Ross, C. W. and Gupta, R. 2018. A review of tillage practices and their potential to impact the soil carbon dynamics. $A d v$ Agron.

doi:10.1016/bs.agron.2018.03.002.

Mulder, C., Schouten, A.J., Hund-Rinke, K., and Breure, A.M. 2005. The use of nematodes in ecological soil classification and assessment concepts. Ecotoxicology Environm Safety, 62 (2): 278-289.

Murugan, R., Josef, Koc.h H., and Joergensen, R.G. 2013. Long-term influence of different tillage intensities on soil microbial biomass, residues and community structure at different depths. Biol. Fertility Soils. 50(3):487-498.

Naresh R.K.; Gupta Raj K.;Gajendra Pal; Dhaliwal S.S.; Kumar Dipender; Kumar Vineet; Arya Vichitra Kumar; Raju; Singh S.P.;Basharullah; Singh Onkar and Kumar Pardeep. 2015. Tillage Crop Establishment Strategies and Soil Fertility Management: Resource Use Efficiencies and Soil Carbon Sequestration in a Rice-Wheat Cropping System. Eco. Env. \& Cons. 21: 121128.

Naresh, R.K., Gupta, Raj K., Singh, S.P., Dhaliwal, S.S., Ashish Dwivedi, Onkar, Singh., et al., 2016. Tillage, irrigation levels and rice straw mulches effects on wheat productivity, soil aggregates and soil organic carbon dynamics after rice in sandy loam soils of subtropical climatic conditions. $J$ Pure Appl MicrobioI, 10(2): 1061-1080.

Naresh, R.K., R.K. Gupta, Vivek, R.S. Rathore, S.P. Singh, Ashok Kumar, Sunil Kumar, D.K. Sachan, S.S. Tomar, N.C. Mahajan, Lali Jat and Mayank Chaudhary. 2018. Carbon, Nitrogen Dynamics and Soil Organic Carbon Retention Potential after 18 Years by Different Land Uses and Nitrogen 
Management in RWCS under Typic Ustochrept Soil. Int. J. Curr. Microbiol. App. Sci. 7(12): 3376-3399.

Neher, D.A. 2001. Role of nematodes in soil health and their use as indicators. $J$ Nematology, 33 (4): 161-168.

Oliveira, D.M.S.; Williams, S.; Cerri, C.E.P.; Paustian, K. 2017. Predicting soil C changes over sugarcane expansion in Brazil using the DayCent model. Glob Chan Biol Bioener. DOI: 10.1111/gcbb. 12427

Pulleman, M., Creamer, R., Hamer, U., Helder, J., Pelosi, C., Peres, G., and Rutgers, M. 2012. Soil biodiversity, biological indicators and soil ecosystem services-an overview of European approaches. Curr. Opinion in Environm Sustainability, 4(5): 529-538.

Paustian, K., J. Lehman, S. Ogle et al., 2016. Climate smart soils. Nature 532:49-57.

Riches, D., Porter, I.J., Oliver, D.P., Bramley, R.G.V., Rawnsley, B., Edwards, J., and White, R.E. 2013. Review: soil biological properties as indicators of soil quality in Australian viticulture. Australian J Grape Wine Res. 19(3): 311-323.

Ruf, A., Beck, L., Dreher, P., Hund-Rinke, K., Rombke, J., and Spelda, J. 2003. A biological classification concept for the assessment of soil quality: "biological soil classification scheme" (BBSK). Agri Ecosyst Environ. 98(1-3): 263-271.

Sarker, J. R., Singh, B. P., He, X., Fang, Y., Li, G. D., Collins, D. and Cowie, A. L. 2017. Tillage and nitrogen fertilization enhanced belowground carbon allocation and plant nitrogen uptake in a semi-arid canola crop-soil system. Sci Rep 7:10726.

Schloter, M., Dilly, O., and Munch, J.C. 2003. Indicators for evaluating soil quality. Agric Ecosyst Environ. 98(1-3): 255262.

Schulte, R.P.O., Bampa, F., Bardy, M., Coyle,
C., Creamer, R.E., Fealy, R., Gardi, C., Ghaley, B.B., Jordan, P., Laudon, H., et al.,2015. Making the Most of Our Land: Managing Soil Functions from Local to Continental Scale. Front. Environ. Sci. 3: 81 .

Scialabba, N. El-Hage, and M. MullerLindenlauf. 2010. Organic agriculture and climate change. Renewable Agric. Food Sys. 25(2): 158-169.

Sharma, V., Hussain, S., Sharma, K.R., and Arya, V.M. 2014. Labile carbon pools and soil organic carbon stocks in the foothill Himalayas under different land use systems. Geoderma (232-234): 8187.

Singh, B. P., Setia, R., Wiesmeier, M. and Kunhikrishnan, A. 2018. Agricultural management practices and soil organic carbon storage. In Soil Carbon Storage, $1^{\text {st }}$ Edition: Modulators, Mechanisms and Modeling (Ed., Singh B.):207-44. Academic Press, London, UK.

Smith, P., D. Martino, Z. Cai et al., 2008. Greenhouse gas mitigation in agriculture. Phil. Trans. Royal Soc. B. 363:789-813.

Smith, J.L., and Paul, E.A. 1990. The signifi cance of soil microbial biomass estimation. In: Bollag J, Stotzky G (eds) Soil Biochem. 6:357-396

Stavi, I.; Bel, G.; Zaady, E. 2016. Soil functions and ecosystem services in conventional, conservation, and integrated agricultural systems: a review. Agron Sustain Dev. 36: 1-12.

Stockmann, U., Adams, M. A., Crawford, J. W., Field, D. J., Henakaarchchi, N., Jenkins, M., Minasny,B., McBratney, A. B., Courcelles, V. de R. de, Singh, K., Wheeler, I., Abbott, L., Angers, D. A., Baldock, J., Bird, M., Brookes, P. C., Chenu, C., Jastrow, J. D., Lal, R., Lehmann, J., O’Donnell, A. G., Parton, W. J., Whitehead, D. and Zimmermann, M. 2013. The knowns, known 
unknowns and unknowns of sequestration of soil organic carbon. Agric. Ecosyst. Environ. 164: 80-99.

Van den Putte, A., Govers, G., Diels, J., Gillijns, K., and Demuzere, M.2010. Assessing the effect of soil tillage on crop growth: A meta-regression analysis on European crop yields under conservation agriculture. Eur. J. Agron. 33: 231-241.

Vandenkoornhuyse, P., Quaiser, A., Duhamel, M., Le Van, A. and Dufresne, A. 2015. The importance of the microbiome of the plant holobiont. New Phytologist 206(4): 1196-206.

Xiao, S.S., Zhang, W., Ye, Y., Zhao, J., and Wang, K. 2016.Soil aggregate mediates the impacts of land uses on organic carbon, total nitrogen, and microbial activity in a Karst ecosystem. Sci Rep. 7:41402 DOI: 10.1038/srep41402

Zheng, H., Liu, W., Zheng, J., Luo, Y., Li, R., Wang, H., et al., 2018. Effect of longterm tillage on soil aggregates and aggregate-associated carbon in black soil of Northeast China. Plos One. 13(6): e0199523.

Zibilske, L. M., Bradford, J.M., and Smart, J.R. 2002. Conservation tillage induced changes in organic carbon, total nitrogen and available phosphorus in a semi-arid alkaline subtropical soil. Soil Tillage Res., 66(2): 153-163.

\section{How to cite this article:}

Mahajan, N.C., Kancheti Mrunalini, K.S. Krishna Prasad, R.K. Naresh and Lingutla Sirisha. 2019. Soil Quality Indicators, Building Soil Organic Matter and Microbial Derived Inputs to Soil Organic Matter under Conservation Agriculture Ecosystem: A Review. Int.J.Curr.Microbiol.App.Sci. 8(02): 1859-1879. doi: https://doi.org/10.20546/ijcmas.2019.802.218 